\title{
ECONOMICS
}

\section{THE NATIONAL AND REGIONAL EFFECTS OF FISCAL DECENTRALISATION IN CHINA}

by

Anping Chen

School of Economics

Jinan University

and

Nicolaas Groenewold

Business School

University of Western Australia 
THE NATIONAL AND REGIONAL EFFECTS OF FISCAL DECENTRALISATION IN CHINA

by

\author{
Anping Chen, \\ School of Economics, \\ Jinan University, \\ Guangzhou, 510632, \\ Guangdong Province, \\ China \\ e-mail: anping.chen@yahoo.com.cn \\ and \\ Nicolaas Groenewold,* \\ Department of Economics, \\ University of Western Australia, \\ Crawley, WA 6009 \\ Australia \\ e-mail: nic.groenewold@uwa.edu.au
}

\title{
DISCUSSION PAPER 11.18
}

*Corresponding author.

We are grateful to the Business School at UWA and to the Department of International Co-operation at Jinan University for grants which supported the visit of Groenewold to Jinan University in 2011. This research was also partially supported by National Natural Science Foundation of China Grant No. 71173092.

The National and Regional Effects of Fiscal Decentralisation in China 


\begin{abstract}
Fiscal decentralisation has played a significant role in the development of China's economy over the past three decades. Yet there has been only limited analysis of the way in which decentralisation might affect variables such as welfare, output and income at the aggregate level and none at the regional level. This paper makes a contribution to redressing this lack by analysing the aggregate and regional effects of various policies which aim to change the balance between fiscal activities of the national and regional governments. We do this within a small theoretical model designed to capture some of the features of the Chinese economy. The model is solved numerically based on a parameterisation using Chinese data. We analyse four different simulations, all of which involve a cut in central government expenditure and a transfer of resources to the regional governments. The policies which we simulate differ according to the assumed reaction of the regional governments: (1)they adjust expenditure on the consumption good, (2) they adjust infrastructure expenditure, (3) they maximise the welfare of the representative citizen, and (4) they maximise the size of their own budget. We find that the aggregate economic effects of decentralisation depend on the precise nature of the policy and that aggregate benefits may often mask a deterioration in the inter-regional distribution of those benefits. ( 220 words)
\end{abstract}

Key words: fiscal decentralisation, regional disparities, growth JEL Classifications: H77, R11, R13, R50 


\section{Introduction}

Decentralisation has been an important aspect of Chinese economic restructuring since the beginning of reforms in the late 1970s. Central-local fiscal relations have evolved over time in two distinct phases since 1978: the transitional phase of 1980-1993, and the post-1994 phase (Jin et al., 2005).

During the 1980s and early 1990s, China initiated a series of decentralisation reforms aimed at promoting local economic growth by providing more incentives to local governments (Zhang, 2006). The highly centralised fiscal system stemming from Soviet Socialism pattern was replaced by the "Fiscal Revenue Share System" (cai zheng bao gan zhi) in 1980, in which the central and provincial governments each began to 'eat in separate kitchens'. Under that system, the fiscal contracts were established from the top down, i.e., the central-provincial revenue-sharing contract was established by the national government, the provincial-prefecture relation was established by the provincial government and so on (Shen et al., 2006). The local government was allowed to retain some revenue if there was a surplus after remitting revenues of a fixed sum to the central government. Thus, the local government had a strong incentive to collect revenue and also promote the development of the local economy and so expand its tax base.

As a result, the local economy and the nation as a whole grew very quickly, with an average annual GDP growth rate of $9.9 \%$ from 1980 to 1993 . However, there were side-effects of the contract system. One of these effects is that the local government could contribute fewer fiscal resources to the central government in order to achieve a higher local economic growth rate by giving local enterprises more incentives such as tax exemptions at the expense of central government revenues (Qiao et al., 2008). Thus, the ratio of central to total revenue has declined 
dramatically from $40.5 \%$ in 1984 to $28 \%$ in 1993 , while local expenditure has grown quickly with the share of local expenditure in total increasing from $45 \%$ in 1981 to $72 \%$ in 1993 while government revenue as a share of GDP decreased dramatically from $25.5 \%$ in 1980 to $12.3 \%$ in 1993 . On the other hand, inter-regional gaps in per capita GDP have been considerably reduced, with the coefficient of variation of provincial per capita GDP dropping from 1.7 in the early 1980 s to 1.4 in 1993 , reflecting the fact that the poor regions grew more quickly than the rich regions during the first phase of decentralization from 1978 to 1993 . The main trends in the division of revenue and expenditure between the central and regional governments are captured in Figure 1.

\section{[Figure 1 about here]}

In order to curb the revenue decline and provide more resources to the government (especially to the central government), the "Tax Assignment System" (fen shui zhi) was introduced in 1994. Under this system, a Value-Added Tax (VAT) was initiated, with the revenue shared between the central and provincial governments, which replaced the previous fixed-remittance scheme in the Fiscal Revenue Share System. The VAT became the most important source of revenue, which alone accounted for about 42\% of total government revenue in 1994 (Ma, 1997). Along with the change in revenue division, the central government tightened its fiscal control by establishing its own revenue collection body, the National Tax Service, in all provinces to collect both central and shared taxes.

The transition to the Tax Assignment System has had significant effects on the fiscal landscape in China. The central government's revenue share in the total jumped from $22 \%$ in 1993 to $56 \%$ in 1994 and then stabilized at about $50 \%$ by 2009 . The decline in the revenue-to-GDP ratio was also halted in 1996; it was reversed and increased steadily from $10.5 \%$ in 1996 to $20.1 \%$ in 2009 . As is clear from Figure 2, 
national GDP has continued to grow quickly, with an average growth rate of $10 \%$ per year from 1994 to 2009 although there have been considerable fluctuations in the growth rate. Moreover, regional disparities which had been declining steadily until 1994, stabilised and then worsened slightly after that year although there has been a further decrease since the mid-2000s. This might indicate that the rich regions which were initially endowed with a broader non-farm tax base and a lighter fiscal burden benefited more than the poor regions that relied heavily on agricultural activity and had few resources left for public investment after paying the expenses of their bureaucracy during the second phase of decentralization (Zhang, 2006).

[Figure 2 here]

It is clear from this brief review that there is no simple relationship between fiscal decentralisation and growth on the one hand and between decentralisation and regional disparities in China on the other and it is not surprising that the decentralisation-growth nexus has been the subject of empirical investigation reported in a number of papers. The reported results are somewhat mixed; Zhang and Zou $(1998,2001)$ found a consistently negative effect while Lin and Liu (2000), Jin et al. (2005), Feltenstein and Iwata (2005), Ding (2007) and Qiao et al. (2008) found positive effects of the fiscal decentralization on growth. It is surprising that there is little work on the effects of decentralisation on regional disparities given that regional disparities have been a key policy concern for the central government for the whole history of the People's Republic of China.

Our paper aims to fill this gap by setting up and solving a small theoretical model to investigate the effects of fiscal decentralisation on regional disparities as well as on aggregate variables. The model is a simple two-region one based on the common distinction in China between the coast and the interior and in which there is 
inter-regional migration in the long run, although it is restricted in a way which captures the household registration or hukou system in China. Moreover, we include various other aspects of the Chinese tax and expenditure system. The model is linearised and solved numerically, based on calibration using Chinese data. The issues of the effects of decentralisation are then addressed by shocking the model in various ways to mimic possible decentralisation policies. We examine the effects on output, income and welfare at the aggregate level and on disparities in these measures as well as on the most common measure of decentralisation: the ratio of regional to aggregate government expenditure.

In addition to our main aim of analysing the aggregate and regional effects of changes in decentralisation, we can also throw light on a variety of issues raised by the empirical literature such as: (i) whether, at the aggregate level, output and welfare always move in the same direction after a decentralisation shock; this would seem to be a minimal requirement for the use of output as a measure of welfare or efficiency in the empirical literature; (ii) whether aggregate measures and disparities tend to move in the same or opposite directions following a decentralisation shock and whether this depends on the way in which the regional governments spend the resources shifted from the national government; and (iii) whether the commonly used measure of decentralisation (the ratio of regional to national government expenditure) is a useful measure of the extent of decentralisation.

The remainder of the paper proceeds as follows. Section 2 reviews the theoretical arguments and empirical work on the effects of fiscal decentralisation with particular attention given to studies of Chinese experience. In section 3 we develop the model after which we set out the simulations in section 4 . The results are reported in section 5 with conclusions presented in section 6 . 


\section{Literature Review}

Fiscal decentralisation is only a part (although an important part) of a broader policy of decentralisation with other components such as administrative and economic decentralisation also having been identified in the literature on the subject. ${ }^{1}$ In this paper we focus on the fiscal aspects of decentralisation and we provide a brief review of the underlying theory before turning to a survey of empirical work which assesses the effects of decentralisation and, finally, summarising the limited literature which deals specifically with China's experience. ${ }^{2}$

The benefits of fiscal decentralisation have been discussed at least since the seminal article by Tiebout (1956) in which he argued that the efficiency with which government resources are allocated may be improved by the assignment of certain functions to lower levels of government - decentralisation. There are several aspects to this argument. First, different regions may have different preferences for a particular local public good so that optimally differential local provision will be more efficient (in the Pareto sense) than uniform national provision at any level (Oates, 1972). Further, local governments may be "closer to the ground" and so are more likely to be able to observe citizens' preferences and provide services at a level that matches local tastes. Finally, this tendency towards an efficient allocation of government resources at the local level will be enhanced by citizens voting with their feet and moving to localities which provide facilities which most closely match their preferences. This mechanism provides a simple and elegant solution to the problem of preference revelation that bedevilled the application of the Samulesonian conditions for (national) public good provision (Samuelson, 1954).

\footnotetext{
${ }^{1}$ See Feltenstein and Iwata (2005) and Yusuf (1994) on these distinctions.

${ }^{2}$ Our discussion of the underlying theory relies on the survey in Vo (2010).
} 
However, while the principles in the ideal case are clear, once the underlying assumptions are relaxed, the effects are less unambiguous. Thus, Oates (2005) pointed out that in practice there are serious barriers to inter-regional migration which will hamper the "voting with feet". Moreover, regional specialisation which is likely to result from the Tiebout mechanism, is also likely to generate regional inequalities which will generate political resistance. As Musgrave (1959) reminded the profession more than half a century ago, efficiency is not the only aim of public finance - there are also stabilisation and distribution - and one might have reservations about the desirability of decentralisation on the grounds that the other two aims of policy are not necessarily well served by it.

A further weakness of the Tiebout mechanism in practice is that of the lack of coincidence between the boundaries relevant for local public goods provision and political administration. Indeed, different local public goods are likely to have different boundaries for their efficient provision, not all of which will be able to be accommodated by political boundaries (Olson, 1969). Brennan and Buchanan (1980) have pointed out that there is no reason in principle why national governments should not provide local public goods at different levels to different regions, although there are likely to be severe restrictions on the political feasibility of inter-regional deviations in many countries.

Another assumption underlying the Tiebout result is that there are no scale economies which would mean that the national government could provide local goods at lower resource costs which might more than offset the inefficiency of sub-optimal local provision (but see Wagner, 2007, for a contrary view). Similarly, externalities must be absent for the Tiebout result to hold. Spillovers, for example, from one region to another which are not taken into account by local governments will result in 
levels of provision which are inefficient compared to the first-best solution although not necessarily compared to uniform national provision. Finally, there is a substantial literature on fiscal federalism which intersects with the analysis of decentralisation. Inter-governmental transfers provide another way in which a national government can influence the behaviour of local governments which may or may not enhance the efficiency of local government public goods provision; early analysis by Scott (1950) and Buchanan (1950) focussed on the distortionary effects of inter-governmental grants. More recent literature such as that by Boadway and Flatters (1982) and Petchey (1995) has shown that there are circumstances in which transfers may be efficiency-enhancing.

Thus, all in all, there are many reasons why the elegant Tiebout mechanism might fail in practice once some of the more restrictive underlying assumptions are relaxed. Moreover, the practice of decentralisation often fails to follow the rules - see e.g., the interesting exchange between Prud'homme (1995) and McLure (1995). It is not surprising, therefore, that researchers have turned to empirical analysis in an attempt to assess the practical effects of fiscal decentralisation and we briefly examine some of the main contribution in what follows.

Much of the empirical literature has focussed on the efficiency effects since that was the thrust of Tiebout's original idea. Before empirical work can begin, at least two difficulties need to be faced. First, whether decentralisation is efficiencyenhancing requires a measure of efficiency or welfare. Since welfare is not observable it must be proxied and most researchers have substituted real income, real output or growth of real output for welfare. This is based on the argument (sometimes explicit but often implicit) that greater efficiency of government resource allocation will result in higher real income, output or growth. 
A second empirical problem is that of devising a measure of decentralisation. As many authors have pointed out, decentralisation is a multi-facetted process, not likely to be captured by a single measure; see the recent paper by Martinez-Vazquez and Timofeev (2010) for a discussion and survey. Nevertheless, for standard econometric estimation, a single or at most a few measures are required and in practice the ratio of local to national government expenditure (or revenue) is a commonly used measure, although many authors also experiment with alternatives to assess the sensitivity of the results to this less-than-ideal measure.

The empirical framework typically employed for the analysis of the effects of decentralisation on output or growth has been the standard growth equation which has real per capita output growth as the dependent variable, a measure of decentralisation as well as a set of standard control variables as independent variables, with the focus being on the coefficient of the fiscal decentralisation measure. Data used has generally been panel data based on a cross-section of countries or of regions within a country.

Early results are surveyed in the paper by Martinez-Vazquez and McNab (2003) and they found that, both theoretically and empirically, it is not clear that fiscal decentralisation benefits growth or output. More recent work does little to resolve this ambiguity. Thus Cantarero and Gonzalez (2009), using panel data for Spanish regions, found little relationship between growth and decentralisation when the latter was measured using expenditure shares but some evidence for a positive relationship in the long run when its measurement was based on revenue shares. These results are similar to those obtained using panel data for a set of eastern European countries by Rodriguez-Pose and Kroijer (2009) who argued that decentralisation is more likely to promote growth when it includes greater access to own revenue by lower level 
governments so that they can more effectively respond to local demands as required by the original Tiebout argument. In a related paper by Rodriguez-Pose et al. (2009) the finding differs by country, with those where decentralisation happens from the top down being less successful in boosting growth than those in which it occurs from the bottom up. A similar result was reported by Im (2010) for a study using a crosscountry panel based on 63 countries: generally the relationship between decentralisation and growth is negative but grouping countries by stage of development suggests that this effect is stronger for developing than developed countries. Finally, a paper by Hammond and Tosun (2011) using more disaggregated data for the US and a larger range of decentralisation measures, also reported mixed findings: the effects of decentralisation depend both on the way in which it is measured and the variable on which the impact is being assessed.

More recently, literature has also analysed the distributional effects of fiscal decentralisation which seems particularly important in light of the common concern that even if decentralisation is growth-enhancing, it may have adverse consequences for regional inequality as it allows the economically stronger regions to press home their advantages and leave the weak even further behind. Like the papers just reviewed, the analysis has generally been undertaken using panel data, either crosscountry or regional and again, the results are mixed, although some patterns seem to emerge. In particular, it appears that the studies using a cross-country panel data set generally find that decentralisation reduces regional inequality while those using a panel based on regions within a country find the opposite - that decentralisation exacerbates regional disparities. In the first group are Canaleta et al. (2004) using a 17-country OECD panel, Ezcurra and Pascual (2008) who used data for a set of EU countries and Lessman (2009) who employed a 23-country OECD data set. All find 
that decentralisation reduces inequality. In the second group are Kim et al. (2003) using a panel of data based on Korean regions, Bonet (2006) who analysed regional data for Colombia and Calamai (2009) who focused on Italian regional data. They all find that decentralisation exacerbates regional disparities. The exception to this pattern is the recent paper by Rodriguez-Pose and Ezcurra (2010) which also used a cross-country panel of data but included both developed and developing countries. Interestingly, they found that the relationship between decentralisation and inequality is weak for the whole sample but negative for the developed countries and positive for the developing countries. Thus, it is possible that the cross-country results reported by others would not continue to hold if the data set were composed of developing rather than developed countries. Whatever the truth of this conjecture may be, it is clear that here, as in the literature on decentralisation and growth, there is no strong consensus of the sign of the relationship.

Turning now to China, the country of particular interest in this paper, we find that there is a number of papers on the relationship between decentralisation and growth but very little reported work on the effect of decentralisation on regional disparities. This is somewhat surprising; although growth has been a central objective of economic policy in China since before the reform period, this has also been true of inter-regional disparities which have also been a matter of great concern since the time of the founding of the People's Republic. ${ }^{3}$

Most of the work analysing the effects of decentralisation has used panel data constructed from annual data for (most of) the Chinese provinces. On the issue of fiscal decentralisation and growth, the results are mixed with two papers by Zhang and Zou $(1998,2001)$ finding a consistently negative effect while papers by Lin and

\footnotetext{
${ }^{3}$ See Groenewold, Chen and Lee (2008) Chapters 2 and 3 for a discussion of regional disparities and regional policy in China from the establishment of the People's Republic until the mid-2000s.
} 
Liu (2000), Jin et al. (2005), Feltenstein and Iwata (2005) and Ding (2007) found positive effects. Only one paper is available which explicitly tests the effects of fiscal decentralisation on both growth and inequality, viz., the paper by Qiao et al. (2008) who found that decentralisation benefits growth but has adverse effects on equality, although it should be noted that equality here means equality in the provincial distribution of fiscal resources, not equality of income or per capita output across provinces which are common measures of inter-regional disparities.

Thus we can make two general conclusions regarding the Chinese literature. The first is that the relationship between fiscal decentralisation and growth has been subject to a reasonable amount of empirical analysis but that the results are ambiguous. Second, while the possibility of adverse effects of decentralisation on inter-regional disparities has been the subject of policy concern in China, they have been very little investigated.

Thus, for the literature as a whole, the empirical work has failed to resolve the theoretical ambiguities which we identified earlier in this survey and this counts for China as well as for the rest of the world. In this paper we return to a theoretical analysis and do so in a framework in which different regions are explicitly modelled. This allows us to analyse the effects of decentralisation on aggregate welfare, output and income as well as on the regional levels and therefore the inter-regional disparities in these variables. While the model is a theoretical one, it focuses on China and is solved numerically using data for the Chinese economy to compute the parameters. 


\section{The model}

The basic regional division of China is into coastal and inland (or interior) regions. These two regions have been the basis for the discussion of regional policy until the mid-1980s. It has also been the scheme used in much empirical work on regional issues in China. ${ }^{4}$ We use this two-region division in our model. The two regions we use are illustrated in Figure 3.

\section{[Figure 3 about here]}

The coastal region is relatively wealthy compared to the interior. Moreover, agriculture which has been central to the Chinese economy is still a major source of income and employment in the inland provinces while its importance has been supplanted by manufacturing in the coast. We capture these stylised facts starkly by assuming a poor interior region (denoted by $I$ ) which produces agricultural goods (denoted by $A$ ) and a wealthy coastal region (denoted by $C$ ) which produces manufactured goods (denoted by $M$ ).

Each region has households, firms and regional governments. There is also a central government. Households supply labour to firms which produce output. Households receive wage and profit income which they use to purchase some of each region's output; in addition, they receive a government-provided consumption good which is private in the rival sense. Firms produce output using three factors - labour, a fixed factor (land or capital) and a government-provided public good (which we call infrastructure). No factors are inter-regionally mobile in the short run but labour can migrate between regions in the long run although there are migration restrictions. In principle, it would be straightforward to introduce capital mobility but this would make the interpretation of the results more complicated and distract from our focus on

\footnotetext{
${ }^{4}$ Recent papers using this classification are Fleisher and Chen (1997), Demurger (2001), Fujita and Hu (2001), Bao et al., (2002), Brun et al. (2002), Hu (2002), Lin et al. (2004), Whalley and Zhang (2007) and He et al. (2008).
} 
labour migration, government behaviour and relative price changes as connections between regions. Besides, there is recent evidence ( $\mathrm{Li}, 2010)$ that capital mobility between China's provinces is much lower than is consistent with free capital mobility.

We distinguish between central and regional governments, with the latter including all sub-national government levels although we recognise that, in practice, the latter level includes several layers (provincial, prefecture, county and township) and in this sense our model is not able to capture the full nuances of fiscal decentralisation in China.

In our model, both levels of government provide households with a consumption good. From the households' perspective the government-provided consumption good is homogeneous. In addition to the consumption good, the regional governments are assumed to provide infrastructure which is an input into the production process. In order to facilitate the analysis of decentralisation, we also include a transfer from the central to the regional governments which the central government may use to provide financing for expenditure responsibilities shifted from the centre to the regions as part of a decentralisation policy.

On the taxation side, we assume three taxes in the model in a way which broadly reflects the stylised facts of the Chinese taxation system: (i) a national VAT, the rate for which is set by the central government at the same level for both regions and the proceeds from which are shared between the central government and the regions with the same shares for each region; ${ }^{5}$ (ii) a business tax levied by the coastal government which is assumed to be levied on the value of manufacturing output; (iii)

\footnotetext{
${ }^{5}$ It would be straightforward to deal with a situation in which shares differ across regions but, again, this would unnecessarily complicate the model.
} 
an agricultural tax which we assume to be levied on the value of agricultural output by the interior government. ${ }^{6}$

We assume that households supply labour inelastically to firms in their own region (each household supplying one unit) and choose consumption to maximise utility. In the coastal region, manufacturing firms choose employment and output to maximise profits, taking the real wage as a parameter and, in the interior, agricultural firms employ all labour and pay a wage equal to the average product of labour. In the first two simulations governments are assumed to behave exogenously (apart from the fact that they need to satisfy their budget constraint) while in the remainder regional governments are assumed to exhibit maximising behaviour.

We consider the behaviour of households, firms and governments in turn. ${ }^{7}$

\subsection{Households}

Households derive utility from the consumption of the two privately-produced goods as well as from a good supplied by governments. We assume a representative household in each region and that the utility function for this household is of the constant-elasticity-of-substitution (CES) form:

$$
V_{i}=\beta_{i}\left(\gamma_{A i} C_{A i}^{-\rho}+\gamma_{M i} C_{M i}^{-\rho}+\delta_{i} G H_{i}^{-\rho}\right)^{\frac{-1}{\rho}}, \quad i=I, C
$$

where $V_{i}=$ utility of the representative household, region $i$,

$$
C_{A i}=\text { real private consumption of agricultural output per household, region } i \text {, }
$$

\footnotetext{
${ }^{6}$ While our structure drastically simplifies the structure of Chinese taxes, we would argue that it captures the salient features; see Lin and Liu (2000), Zhang and Martinez-Vazquez (2003), Jin et al. (2005), Shen et al. (2006), Jin and Zou (2005), Tochkov (2007), Zhang and Zou (1998, 2001) and Zhang (2006) for recent information on aspects of the Chinese public finances. It should also be noted that the tax on agriculture was abolished in 2006. We nevertheless include it in our model since for much of the postwar period it has been an important source of revenue for the interior provincial governments. But it would be possible to replace it with an alternative that falls more heavily on the interior provinces and is an important source of revenue for them.

${ }^{7}$ A list of variables is given in Appendix 1.
} 
$C_{M i}=$ real private consumption of manufactured good per household region $i$,

$G H_{i}=$ real government-provided consumption per household, region $i$.

$\beta_{i}=$ the scale parameter, region $i$,

$\gamma_{j i},=$ the share parameters, region $i, \operatorname{good} j$,

$\delta_{\mathrm{i}}=$ the share parameter for the government consumption good, region $i$

$\rho=$ the substitution elasticity parameter (the elasticity of substitution is $1 /(1+\rho))$

with:

$$
\begin{array}{ll}
\beta_{i}>0, & i=I, C, \\
0<\gamma_{j i}<1, & j=A, M, \quad i=I, C, \\
0<\delta_{i}<1, & i=I, C, \\
\gamma_{A i}+\gamma_{M i}+\delta_{i}=1 & i=I, C, \text { and } \\
\rho>-1 . &
\end{array}
$$

To formulate the household budget constraint we need to combine quantities of the two goods in a single measure. We do this using the price of a composite good which we will later also use to define national output and income as well as the government good which, in the case of the central government, will also include both regional goods. ${ }^{8}$ The (national) composite good has a price index:

$$
P_{C}=\left(P_{A}\right)^{\lambda}\left(P_{M}\right)^{1-\lambda}
$$

where $P_{j}$ is the price of good $j(j=A, M)$ and $\lambda$ is the share of agricultural output in total output.

We model income net of the VAT and account for the tax when we define income below. This is possible because of the simple structure of the model which

\footnotetext{
${ }^{8}$ An alternative is to use one of the two goods as numeraire. But given the regional specialisation of production, the choice of numeraire will have important effects on the regional comparisons if relative prices change.
} 
implies that the VAT is equivalent to a tax on the value of final consumption (since there are no intermediate goods) and, given that households spend all their income, it is also equivalent to an income tax. Using the price index for the composite good, the household budget constraint for region $i$ can be written as:

$$
\left(P_{A} C_{A i}+P_{M} C_{M \mathrm{i}}\right) / P_{C}=J_{i}
$$

or, using the definition of $P_{C}$ and letting $P$ denote the price of agricultural goods in terms of manufacturing goods, $P=P_{A} / P_{M}$, as

$$
P^{I-\lambda} C_{A i}+P^{-\lambda} C_{M i}=J_{i}, \quad i=I, C
$$

where $J_{i}=$ household income (net of VAT) in terms of the composite good in region $i$. Utility maximisation subject to the household budget constraint gives the demand functions:

$$
\begin{aligned}
& C_{A i}=\frac{J_{i} P^{\lambda-1}}{P^{-1}\left(P \frac{\gamma_{M i}}{\gamma_{A i}}\right)^{\frac{1}{\rho+1}}+1}, \quad i=I, C \\
& C_{M i}=\frac{J_{i} P^{\lambda-1}}{P^{-1}+\left(P \frac{\gamma_{M i}}{\gamma_{A i}}\right)^{\frac{-1}{\rho+1}}}, \quad \quad i=I, C .
\end{aligned}
$$

Household income consists of wages and profits, both of which are measured in terms of the output produced by the firm paying the wages and profits. Since we assume regional specialisation in production, the wage received by households in the interior is the agricultural wage, $W_{A}$, and the coastal wage is equivalent to the manufacturing wage, $W_{M}$. We measure income in terms of the composite good so that we have the following relationship between income, the sources of income (wages and profits) and the VAT rate, $T_{V}$ (which we treat as an income tax):

$$
\begin{aligned}
& \left(1+T_{v}\right) J_{I}=P^{1-\lambda}\left(\Pi H_{I}+W_{A}\right), \\
& \left(1+T_{v}\right) J_{C}=P^{-\lambda}\left(\Pi H_{C}+W_{M}\right),
\end{aligned}
$$


where $\Pi H_{i}=$ profit distribution per household, region $i$, and

$$
W_{j}=\text { real wage income per household, sector } j \text {. }
$$

Inter-regional migration has been an important spatial equilibrating mechanism in regional models although, in practice, it has generally been found to act rather slowly. In China, too, it has played a crucial role in spreading the benefits of economic development from the coast to the interior and, moreover, it has been the subject of very detailed policy intervention in the form of the household registration system or hukou. In our model we allow for migration from one region to another, although given the slow reaction of migration to economic incentives, we allow for it only in the long run. Further, we assume there are migration restrictions of the hokou type which we model as increasing the costs of migration. ${ }^{9}$ To simplify the analysis, we assume that migration occurs only from the poor to the rich region. This avoids the discontinuities which result from two-way costly migration; see Mansoorian and Myers (1993) for an analysis of a model with such discontinuities and Woodland and Yashida (2006) for an approach similar to ours but applied to immigration from poor to rich countries. ${ }^{10}$

In the models with free migration it is customary to assume that migration occurs until utility is equalised across regions. But under the hukou system, people will be worse off in the interior since they will have to incur costs to obtain hukou for the coastal region. We model the migration equilibrium condition as:

$$
V_{C}=\left[\frac{L_{M} / A_{C}}{L_{A} / A_{I}}\right]^{\mu} V_{I}, \mu>0
$$

\footnotetext{
${ }^{9}$ See Cheng and Selden (1994) and Liu (2005) for a general description and history of the hukou system.

${ }^{10}$ Other authors (such as Boadway and Flatters, 1982, Myers, 1990, Petchey, 1993, 1995, Petchey and Shapiro, 2000, Groenewold, Hagger and Madden, 2000, 2003, and Groenewold and Hagger, 2005, 2007) have avoided the discontinuity by assuming migration to be costless but this will not do in our case since we model the hukou restrictions in terms of migration costs.
} 
where $L_{i}$ is the population and $A_{i}$ the area of region $i$ so that $L_{M} / A_{C}\left(=L_{C} / A_{C}\right)$ is the population density in the coastal region and $L_{A} / A_{I}\left(=L_{I} / A_{I}\right)$ is the population density in the interior region; $\mu$ can be thought of as the hukou parameter - the larger is $\mu$ the greater will be the difference in utilities across the two regions (since the coastal population density exceeds that in the interior so that the term in brackets exceeds one). The intuition is that the higher the population density the more resistant will the coastal region be to further migration from the interior provinces. We use population density rather than population itself since the latter will depend on the number of provinces in a region and not capture the idea that it is the perceived capacity of the coastal region to absorb more population that is one of the factors behind the coast's resistance to migration from the interior provinces.

\subsection{Firms}

We assume that the number of firms in each region is fixed. The firms in the interior region engage in agriculture and in the coastal region they engage in manufacturing. In each region, firms hire labour from households in their own region and combine it with a fixed factor and the infrastructure provided by the regional government to produce output using constant-returns-to-scale Cobb-Douglas technology.

In the interior the fixed factor is called land and we assume that each firm (or farm in this case) is allocated the same amount of land of identical quality. Workers are assumed to choose a farm on which to work so as to achieve the highest wage. Firms, in turn, pay all workers the average product so that in equilibrium the average product of labour is equalised across all agricultural firms which requires that they are all of the same size. We can therefore assume, without loss of generality, that there is 
only one firm in the interior region and we analyse a representative agricultural firm which has the following production function:

$Y_{A}=B_{A}(L A N D)^{\left(1-\alpha_{A L}-\alpha_{A G}\right)}\left(L_{A}\right)^{\alpha_{A L}}\left(G R F_{A}\right)^{\alpha_{A G}}, 0<\alpha_{A L}, \alpha_{A G},\left(1-\alpha_{A L}-\alpha_{A G}\right)<1$

where $B_{A}$ is total factor productivity (TFP), $L_{A}$ is the total labour in agriculture (also the total population in the inland region) and $G R F_{A}$ represents regional government expenditure on infrastructure which benefits firms. Since we assume land to be an immobile factor in fixed supply, we can simplify and write:

$$
D_{A}=B_{A}(L A N D)^{\left(1-\alpha_{A L}-\alpha_{A G}\right)}
$$

so that the production function becomes:

$$
Y_{A}=D_{A}\left(G R F_{A}\right)^{\alpha_{A G}}\left(L_{A}\right)^{\alpha_{A L}}, \quad 0<\alpha_{A L}, \alpha_{A G},\left(1-\alpha_{A L}-\alpha_{A G}\right)<1
$$

where $D_{A}$ incorporates both the available agricultural land and TFP.

We proceed along the same lines for firms in the coastal region which engage in manufacturing. In this region the fixed factor is capital which is not interregionally mobile and, again, it is assumed to be distributed in equal amounts amongst the fixed number of manufacturing firms. Since all firms maximise profits, they will be of the same size and we can again assume that there is only one and analyse the typical firm which has a production function of the form:

$$
Y_{M}=B_{M}(C A P I T A L)^{\left(1-\alpha_{M L}-\alpha_{M G}\right)}\left(L_{M}\right)^{\alpha_{M L}}\left(G R F_{M}\right)^{\alpha_{M G}}, \quad 0<\alpha_{M L}, \alpha_{M G},\left(1-\alpha_{M L}-\alpha_{M G}\right)<1
$$

We can simplify, as before, by writing:

$$
D_{\mathrm{M}}=B_{M}(C A P I T A L)^{\left(1-\alpha_{M L}-\alpha_{M G}\right)}
$$

so that the production function for manufacturing becomes:

$$
Y_{M}=D_{M}\left(G R F_{M}\right)^{\alpha_{M G}}\left(L_{M}\right)^{\alpha_{M L}}, 0<\alpha_{M L}, \alpha_{M G},\left(1-\alpha_{M L}-\alpha_{M G}\right)<1
$$


Again, $D_{M}$ can be interpreted as capturing TFP as well as capital in manufacturing.

We can write the production functions for both regions as:

$$
Y_{j}=D_{j}\left(G R F_{j}\right)^{\alpha_{j G}}\left(L_{j}\right)^{\alpha_{j L}}, \quad 0<\alpha_{j L}, \alpha_{j G},\left(1-\alpha_{j L}-\alpha_{j G}\right)<1, \quad j=A, M
$$

Consider now firms' behaviour. Profits (in terms of the firm's own output) are defined as:

$$
\Pi F_{j}=\left(1-T_{j}\right) Y_{j}-W_{j} L_{j}, \quad j=A, M
$$

where $T_{A}$ is the tax on agricultural output levied by the government of the interior region and $T_{M}$ is the tax levied by the coastal region's government on manufacturing output. ${ }^{11}$ We assume that the firm in each industry takes the wage, the tax rate and the quantity of infrastructure as given. Hence the only choice variable in each case is the level of employment (which will also determine output via the production function). Following a long tradition in the economic development literature (Lewis, 1954, Mellor and Stevens, 1956, Gutman, 1957, Robinson, 1971, and Rey, 1998), we make different behavioural assumptions for the two sectors - manufacturing firms in the coastal region are assumed to choose employment to maximise profits but in the inland region all workers are assumed to find employment in agriculture with the farm output being shared equally among all workers. In agriculture, therefore, the wage is equal to the average product and profits are zero.

The profit-maximising condition for manufacturing firms will result in the usual marginal productivity condition:

$$
\left(1-T_{M}\right) \alpha_{M L} D_{M}\left(G R F_{M}\right)^{\alpha_{M G}}\left(L_{M}\right)^{\alpha_{M L}-1}=W_{M}
$$

\footnotetext{
${ }^{11}$ Note that, given our simplifying assumptions, the VAT imposed in the coastal region is equivalent to the manufacturing tax (they are both effectively levied on the value of output) and the VAT imposed in the interior is equivalent to the tax on agriculture except that the implications via the budget constraints differ - the VAT has implications for both regions via the central government's budget constraint while the manufacturing tax has implications only for the coastal region and the agricultural tax only for the interior.
} 
In agriculture the assumption that labour is paid its average product results in the following condition:

$$
\left(1-T_{A}\right) D_{A}\left(G R F_{A}\right)^{\alpha_{A G}}\left(L_{A}\right)^{\alpha_{A L}-1}=W_{A}
$$

On the labour supply side, each household in each region is assumed to provide one unit of labour inelastically to the firms in its own region. We assume that wages adjust to clear labour markets so that labour force, labour supply, employment, the number of households and population are all equal and we use the same notation for them all: $L_{j}$.

\subsection{Governments}

There are three primary sources of government revenue. The central government levies a VAT at a uniform rate across the country and shares the revenue with the regional governments. In addition, each regional government has its own tax: the coastal government raises revenue through a business tax on manufacturing output and the inland government levies an agricultural tax on the value of farm output. Finally, there are lump-sum transfers from the central to the regional governments. Each government (central, coastal and interior) receives tax revenue in the form of output and costlessly transforms this output into a homogeneous government good. The central government provides this to households as a consumption good in both regions, in per capita amounts which are the same for all households within the region but may differ across regions. Each regional government provides some output to households as a consumption good (in equal per capita amounts) within its own region as well as providing some to firms as infrastructure.

There are no assets in the model so that neither households, nor firms nor governments can lend or borrow. Governments therefore must balance their budgets. 
Consider the central government first. It raises VAT of $L_{A} T_{V} J_{I}$ in region I and $L_{M} T_{V} J_{C}$ in region $\mathrm{C}$. Of this, a proportion $(1-\theta)$ is transferred to the regional governments, a lump-sum amount $T R_{i}$ (measured in terms of the composite good) is transferred to regional government $i$ and the remainder is transformed costlessly into the government consumption good. The production process for the government good is very simple: we assume that one unit of the composite good can be transformed into a unit of the government good. The central government receives VAT revenue which is levied on incomes which are measured in terms of the composite good. Its budget constraint therefore has the form:

$$
L_{A} G C_{I}+L_{M} G C_{C}=\theta T_{V}\left(L_{A} J_{I}+L_{M} J_{C}\right)-T R_{I}-T R_{C}
$$

where $G C_{i}(i=I, C)$ is government good per household provided to residents of region $i$, $T_{V}$ is the VAT rate and $\theta$ is the central government's share of the VAT proceeds.

The regional governments receive some revenue from the VAT reimbursement and a lump-sum transfer, both from the central government and both measured in terms of the composite good. They also derive revenue some from local firms which is measured in terms of the firm's own output and is therefore re-valued in terms of the composite good before being transformed into the government good. The regional governments' budget constraints have the form:

$$
\begin{aligned}
& L_{A} G R H_{I}+G R F_{A}=T_{A} P^{l-\lambda} Y_{A}+(1-\theta) T_{V} L_{A} J_{I}+T R_{I} \\
& L_{M} G R H_{C}+G R F_{M}=T_{M} P^{-\lambda} Y_{M}+(1-\theta) T_{V} L_{M} J_{C}+T R_{C}
\end{aligned}
$$

In addition to the government budget constraints, we also introduce a variable of the type which has been commonly used in the empirical analysis of the effects of decentralisation, viz., the ratio of regional to aggregate government expenditure. We denote the variable $D E C E X$ and define it as:

$$
D E C E X=\frac{G R F_{A}+L_{A} G R H_{I}+G R F_{M}+L_{M} G R H_{C}}{G R F_{A}+L_{A} G R H_{I}+G R F_{M}+L_{M} G R H_{C}+L_{A} G C_{I}+L_{M} G C_{C}}
$$


where the numerator is simply regional government expenditure (aggregated over the regions and over the two expenditure types) and the denominator is aggregate government expenditure (aggregated over the two levels of government and the two expenditure types). A rise in $D E C E X$ will be taken as indicating greater decentralisation. An alternative, but less common, measure of the extent of decentralisation is the revenue share measured similarly to $D E C E X$ which we do not introduce explicitly since the lessons we wish to draw from the use of this type of summary variable can be adequately drawn from the use of $D E C E X$.

It is common to assume that governments act exogenously and two of our four policy simulations will be based on this assumption. We also experiment, however, with the alternative that governments, like private agents, are also maximisers. In our case we entertain this possibility only for the regional governments and make two alternative assumptions corresponding to what seem like the two most likely alternative motivations for regional governments - their own interests or the interests of their citizens. So we consider the two cases: that they maximise the size of their budgets (empire-building regional governments) and that they maximise the welfare of the representative household in their region (beneficent regional governments). ${ }^{12}$ For the empire building case we assume that they maximise $L_{j} G R H_{i}+G R F_{j}(i=I, C$, $j=A, M$ ) by choosing $G R F_{j}$ with $G R H_{i}$ being taken as given. This results in the following maximisation conditions

$$
\begin{aligned}
& \text { (11a) } 1+L_{A} \frac{\partial G R H_{I}}{\partial G R F_{A}}+G R H_{I} \frac{\partial L_{A}}{\partial G R F_{A}}=0 \\
& \text { (11a) } 1+L_{M} \frac{\partial G R H_{C}}{\partial G R F_{M}}+G R H_{C} \frac{\partial L_{M}}{\partial G R F_{M}}=0
\end{aligned}
$$

\footnotetext{
${ }^{12}$ We consider strategic behaviour only for the regional governments, not because we think this is more likely to describe them than the central government but because we are interested in the strategic reaction of the regional governments to central government fiscal initiatives.
} 
For the beneficent government, we assume that it maximises utility $V_{i}(i=I, C)$ by choosing $G R H_{i}$ with $G R F_{j}$ taken as given. ${ }^{13}$ The condition for maximisation in this case is:
(11c) $\gamma_{A I} C_{A I}^{-\rho-1} \frac{\partial C_{A I}}{\partial G R H_{I}}+\gamma_{M I} C_{M I}^{-\rho-1} \frac{\partial C_{M I}}{\partial G R H_{I}}+\delta_{I} G H_{I}^{-\rho-1} \frac{\partial G H_{I}}{\partial G R H_{I}}=0$
(11d) $\gamma_{A C} C_{A C}^{-\rho-1} \frac{\partial C_{A C}}{\partial G R H_{C}}+\gamma_{M C} C_{M C}^{-\rho-1} \frac{\partial C_{M C}}{\partial G R H_{C}}+\delta_{C} G H_{C}^{-\rho-1} \frac{\partial G H_{C}}{\partial G R H_{C}}=0$

\subsection{Aggregate variables and closure}

It remains to introduce a number of important aggregate variables, definitions and market-clearing conditions to complete the specification of the model.

First, the aggregate counterparts to the regional variables are defined. We begin with aggregate output. Recall that regional output is measured in terms of the good produced in the region - agriculture in the interior and manufacturing in the coast. We measure national output in terms of the composite good and so first convert each region's output to the composite good before combining them:

$$
Y=P^{I-\lambda} Y_{A}+P^{-\lambda} Y_{M}
$$

For income, we simply add total income (per capita income multiplied by population) of each region since they are already measured in terms of the composite good:

$$
J=L_{A} J_{I}+L_{M} J_{C}
$$

The appropriate procedure for welfare is less straightforward because of the problem of the inter-personal comparison of utilities. This is not a problem at the regional level since we assume that all the households within a region are identical but, since households may differ across regions, the same procedure is not obviously correct at

\footnotetext{
${ }^{13}$ Note that we assume the choice variable in the empire-building case to be infrastructure expenditure while in the welfare-maximising case we assume that the regional governments choose consumption expenditure. This reflects the view that governments are more likely to see consumption as determining welfare but infrastructure as affecting the size of their revenue.
} 
the national level. We decide to treat the individuals of the two regions equally and simply measure national welfare as the population-weighted average of the utilities of the two types of identical households:

$$
V=\left(L_{A} / L\right) V_{I}+\left(L_{M} / L\right) V_{C}
$$

where $L$ is national population.

Next, we introduce the relationship between $G H_{i}$ and its components which is given by:

$$
G H_{i}=G R H_{i}+G C_{i}, \quad i=I, C
$$

Goods-markets clearing in each region is assumed and implies:

$$
F_{A} Y_{A}=L_{A} C_{A I}+L_{M} C_{A C}+T_{A} F_{A} Y_{A}+T_{V} L_{A} P^{\lambda-1} J_{I}
$$

$$
F_{M} Y_{M}=L_{A} C_{M I}+L_{M} C_{M C}+T_{M} F_{M} Y_{M}+T_{V} L_{M} P^{\lambda} J_{C}
$$

where we use the fact that in each case income is measured in terms of the composite good while consumption and output are measured in terms of output of agricultural and manufacturing goods.

Firms are assumed to distribute all their profits to households in their own region in equal per capita amounts:

$$
\Pi F_{A}=L_{A} \Pi H_{I}
$$

$$
\Pi F_{M}=L_{M} \Pi H_{C}
$$

The trade between regions must balance:

$$
L_{M} P C_{A C}=L_{A} C_{M I}
$$

Finally, there is a given national labour force (= population), $L$, which we assume to be exogenous:

$$
L_{A}+L_{M}=L
$$

To summarise, the model (with exogenous regional governments) consists of the 30 equations, (1) to (10) and (12-19) in 41 variables: 
$V_{i}, C_{j i}, G H_{i}, P, J_{i}, \Pi H_{i}, D_{j}, Y_{j}, L_{j}, \Pi F_{j}, T_{V}, T_{j}, W_{j}, T R_{i}, G R H_{i}, G R F_{j}, G C_{i}, \theta, D E C E X, L$, $\mu, Y, J, D E C E X$ and $V$,

of which 13 are exogenous:

$D_{j}, T_{j}, T R_{i}$, one of $\left(G R H_{I}, G R F_{A}\right)$, one of $\left(G R H_{C}, G R F_{M}\right)$, one of $\left(G C_{I}, G C_{C}\right), \theta,, T_{V}, L$, and $\mu$,

so that there are 28 endogenous variables:

$V_{i}, C_{j i}, G H_{i}, P, J_{i}, \Pi H_{i}, Y_{j}, L_{j}, \Pi F_{j}, W_{j}, Y, J, V$, one of $\left(G R H_{I}, G R F_{A}\right)$, one of $\left(G R H_{C}\right.$, $\left.G R F_{M}\right)$, one of $\left(G C_{I}, G C_{C}\right)$ and $D E C E X .^{14}$

Two equations, however, are redundant since (3), (6), (17), (18) and the household budget constraint can be used to derive (16) so that the balance between number of equations and number of endogenous variables is restored. When we extend the model to include maximising governments, we add two equations, (11a) and (11b) for the empire-building case and (11c) and (11d) for the beneficent case, and switch two regional government variables from the exogenous to the endogenous category to maintain equality between the number of equations and the number of endogenous variables.

\subsection{Short-run and long-run versions of the model}

In the simulations to be reported below we distinguish between short-run and long-run versions of the model. Since the model is static rather than dynamic, the distinction is not based on the notion of equilibrium but corresponds, as in Krugman (1991), to differences in closure assumptions. In particular, we define the short run as the length of time before inter-regional migration begins to respond to the changes in $V_{I}$ and $V_{C}$. The distinction is based on the idea that migration is slow to respond fully

\footnotetext{
${ }^{14}$ Note that, strictly-speaking we should include the two $A_{j}$ as variables and declare them exogenous. But since they are areas of the two regions and there seems no possible exercise which would require shocks to them, we treat them as parameters.
} 
to changes in economic incentives. Thus, for example, Pissarides and McMaster (1990) estimate that it takes as long as 20 years for reasonably complete adjustment of migration to labour-market shocks. In terms of the model, this simply involves suspending equations (4) and (19) and making $L_{A}$ and $L_{M}$ exogenous in the short-run simulations. The long run is used to refer to the simulation results using the model as set out above.

\subsection{Linearising the model}

The model as it stands is too complicated to solve analytically so that we linearise it in terms of proportional changes for which we use a process of log differentiation. This converts the model from one which is non-linear in the levels to one which is linear in the proportional rates of change of the variables. The resulting linearised versions of equations (1) - (19) are given in Appendix 2.

\subsection{The numerical version of the linearised model}

Having linearised the model in terms of proportional changes, we can solve the model for any one of the (changes in the) endogenous variables in terms of (the changes in) the exogenous variables. However, given the number of endogenous variables, this is unlikely to lead to any interpretable results and we proceed to solve the model numerically using data for China's regions to calibrate the key parameters of the model, detailed discussion of which we relegate to Appendix 3.

\section{The simulations}

We run four different simulations of the model to mimic plausible decentralisation policies. In each policy the basis is a transfer of resources from the 
central government to the regional government. The central government "finances" the increased transfers by cutting its consumption expenditure equi-proportionately in each region. Numerically, we specify the policy so that the proportional changes in $T R_{I}$ and $T R_{C}$ are each $1\left(t r_{I}=t r_{C}=1\right.$ in the notation of the linearised model $\left.{ }^{15}\right)$. The policies differ according to the assumption we make about the reactions of the regional governments.

(1) Policy 1. The regional governments are assumed to react to the increase in their resources by increasing spending on the government consumption good. This policy is therefore essentially a substitution of regional for central government consumption expenditure.

(2) Policy 2. The regional governments are assumed to spend the extra resources on the infrastructure good supplied to firms in their region. This policy therefore not only shifts expenditure from the central government to the regional governments but also changes the composition of total spending, substituting infrastructure spending for consumption expenditure.

(3) Policy 3. The regional governments are assumed to react strategically to the transfer of resources from the central government in the sense that they adjust their spending so as to maximise the size of their budget.

(4) Policy 4. The regional governments are assumed to adjust their spending so as to maximise the welfare of their representative citizen.

\footnotetext{
${ }^{15}$ In the linearised version of the model lower-case variables are used to denote the proportional changes in their upper-case counterparts; thus, e.g., $t r_{I}$ is the proportional change in $T R_{I}$.
} 
5. The results

The simulation results are reported in Table 1. We discuss the effects of each policy in turn.

\section{[Table 1 about here]}

\subsection{Policy 1}

All four simulations involve an equal unit transfer from the central to each of the two regional governments $\left(\operatorname{tr}_{I}=t r_{C}=1\right)$ and assume that the central government maintains budget-balance by varying its level of (consumption) expenditure; since there are two of these variables - one for each region - we assume that the change in these components is equal across regions $\left(g c_{C}=g c_{I}\right)$ to match the equality in proportional transfers. For the regional governments we assume that they also balance their budgets by adjusting consumption expenditure. Thus, essentially, the policy being considered is a shift of consumption expenditure from the centre to the regions balanced by a transfer of resources to the regional governments.

The results in Table 1 show that there are few effects of this policy in the short run which is not surprising since it involves mainly a change in the level of government which provides households with the government consumption good. The policy does involve some regional redistribution, though, since the equal percentage transfer to the regional governments means a greater addition to the interior government's budget than to the coastal budget, reflecting the fact that the interior government is more heavily dependent on the transfer than the coastal government is. The result is that the interior government is able to expand its consumption expenditure by more than the central government's expenditure contraction and vice versa for the coastal government which, in turn, results in welfare increasing in the interior but falling in the coast. Moreover, the adverse consequences in the coast are 
more severe than the beneficial effects in the interior so that national welfare falls. Finally, the decentralisation index $D E C E X$ (the ratio of regional to total government expenditure) rises so that in this sense decentralisation clearly occurs. All in all, this is a successful fiscal decentralisation in the sense that DECEX increases but in doing so, interior welfare increases, coastal welfare falls and national welfare falls. On the whole, therefore, decentralisation makes the average citizen worse-off.

In the long run people migrate to the region which has become relatively better-off, in this case from the coast to the interior. ${ }^{16}$ The immediate effect of this is to boost labour supply and employment in the interior and reduce them in the coast. This, in turn, increases output in the interior and reduces it in the coast. However, the falling marginal productivity of labour means that per capita output moves in the opposite direction, falling in the interior but rising in the coast. The fall in manufacturing output in the coast more than offsets the rise of agricultural output in the interior so that national output falls as a result of the migration. Similarly, the fall in marginal product of labour depresses the wage and, so, income in the interior and raises it in the coast so that the income gap widens and aggregate income falls. On the welfare front, while migration reduces the welfare gap compared to the short-run situation, it still moves in favour of the interior relative to the initial equilibrium and national welfare is still adversely affected by the policy. Finally, the DECEX index does not change a great deal compared to the short-run situation.

We summarise the effects of this fiscal decentralisation policy as follows. The standard measure of fiscal decentralisation, the ratio of regional to total government expenditure, clearly rises reflecting the shift of expenditure from the centre to the

\footnotetext{
${ }^{16}$ It may seem implausible that people migrate from the coast to the interior when the dominant migrations in China in the last three decades has been in the opposite direction. But we might think of the effect in the model as simply a reduction of the rate of migration that would otherwise have occurred.
} 
regions. However, the policy is generally not beneficial; for the economy as a whole, welfare, income and the level of output all fall and inter-regional disparities of income and output per capita both widen. In contrast, the welfare gap between the interior and the coast narrows so that from this point of view the policy is beneficial.

\subsection{Policy 2}

Recall that this simulation is similar to the previous one except that the variable which is assumed to adjust to satisfy the regional governments' budget constraints is infrastructure spending. In this case we can see the policy as one in which the central government shifts resources to the regions by cutting its consumption expenditure while the regional governments use the resources to boost their infrastructure expenditure so that there is not only an inter-governmental resource shift but also a change in the national expenditure mix from consumption to infrastructure. The results are reported in columns four and five of Table 1.

Consider the short-run effects first. They are more extensive than those in the previous case since the substitution of (regional) infrastructure expenditure for (central) consumption expenditures has widespread effects via production even in the short run. The first effects to be noted are those on output - the output in both regions increases, with manufacturing output in the coast increasing less because of the lower marginal product of infrastructure in manufacturing. The much greater increase in agricultural output results in a substantial fall in the price of agricultural goods relative to manufacturing goods. Not surprisingly, aggregate output (in terms of the composite commodity) increases too. As output increases, so too do wages, profits and incomes in both regions as well as in the country as a whole. The increase in income generally leads to higher consumption and welfare. However, in the interior 
the steep increase in the relative price of manufactures results in a small fall in the consumption of manufactures and, together with the cut in central government provision of the consumption good, welfare falls overall in the interior while it rises in the coast. Thus, in the short run the DECEX index increases reflecting a shift of expenditure to the regions and at the national level, output, output per capita, and welfare all increase, suggesting a successful policy. However, the effects on interregional disparities are generally unfavourable - although the per capita output gap narrows, the income and welfare gaps widen.

In the long run the widening welfare gap between the regions induces migration from the interior to the coast which, of itself, further increases output in the coast and reduces it in the interior. However, the reduction in interior population releases resources to the interior government (since the provision of the government consumption good is assumed constant per capita in this simulation) which it uses for a further increase in infrastructure expenditure which, in turn, boosts output by more than enough to offset the reduction due to the loss of labour to the coast. Thus there is a further increase in output in both regions as the economy transitions from the short to the long run. Falling marginal productivity of labour, however, means that output per capita falls in the coast relative to the short run although it still exceeds that in the initial equilibrium. Thus, in the long run, relative to the initial situation, this policy increases aggregate output, income and welfare and also increases all of these measures for each region. The changes at the regional level, though, result in a widening of the inter-regional gaps in both welfare and income while the per capita output gap narrows. These adverse effects for disparities, however, are not as serious as in the previous case - in the present case all regional magnitudes move favourably 
but the change is less favourable for the interior than it is for the coast. All this is matched by a rise in the decentralisation index, DECEX.

We might conclude, then, that this second policy is more successful than the previous one - both are clear cases of fiscal decentralisation as evidenced by the rise in $D E C E X$ but the second policy has generally favourable economic effects in both regions although overall the coast fared better, making for widening inter-regional gaps in income and welfare. Perhaps this policy is closer to what commentators have in mind in informal analysis of the benefits of decentralisation - the funds which are shifted from the centre to the regions are better utilised by the regions than they were by the centre, resulting in a more efficient overall employment of resources and improved welfare, although not everyone shares equally in the improvement.

\subsection{Policy 3}

Consider next the first of two policies in which we assume that regional governments react strategically to the central government's fiscal decentralisation. The first of these, the empire-building case, assumes that regional governments act to maximise the size of their budgets. In terms of the model, two equations (11a and 11b) are added to the model and both the regional-government expenditure variables are now endogenous. The results for this policy are reported the sixth and seventh columns in Table 1.

The short-run effects are identical to those resulting from the previous policy. This is because the first-order condition requires that the change in $G R H_{i}$ is proportional to $L_{i}$ which is exogenous in the short run. ${ }^{17}$ Hence infrastructure expenditure adjusts to satisfy the regional government's budget in each region which

\footnotetext{
${ }^{17}$ The reader will recall that the choice variable in the maximising problem underlying equations (11a) and (11b) is $G R F_{j}$. We might instead have assumed that $G R H_{i}$ was used to achieve the maximum. Simulations based on this alternative show that the overall conclusions are not affected by this choice.
} 
is exactly the assumption underlying policy 2 . As in that case, welfare falls in the interior and rises in the coast, causing migration to the coast. In the long run the results differ from the previous case since regional governments can adjust both consumption and infrastructure expenditures subject to their budget constraints. The interior government uses the opportunity of departing population to increase per capita consumption expenditure while the coastal government does the opposite - as more people move in from the interior it reduces per capita expenditure on the government consumption good. This results in less being left over for infrastructure expansion in the interior and more in the coast compared to the previous simulation and this has flow-on effects for output although these are also affected by population flows. Since the differences to the previous case are relatively small, we can conclude that strategic behaviour has similar effects to those which obtain when the regional government adjusts only infrastructure expenditure. However, since the differences between the policies 1 and 2 are substantial, it is clear that empire-building behaviour produces quite different effects to the policy 1 in which consumption expenditure is the regional governments' endogenous variable. It is interesting, finally, to compare the changes in the size of the government's budget in the three cases. For the interior government the long-run increases in its expenditure levels are $0.571,0.618$ and 0.621 for the three policies respectively. Thus, in all cases the interior region's government expenditure increases as a result of the decentralisation exercise but the increase is bigger when the extra resources are used for infrastructure expenditure; the benefit from empire-building behaviour are small. The differences are more dramatic for the coast for which the corresponding figures are $0.270,0.622$ and 0.607 . Thus the coastal government's budget increases dramatically when it spends the extra resources 
on infrastructure but actually increases by slightly less when it switches to strategic behaviour, clearly because of the interaction with the interior region's government.

\subsection{Policy 4}

Finally consider the second policy in which the strategic behaviour on the part of the regional governments is assumed, in this case behaviour designed to maximise welfare. The results are shown in the last two columns of Table 1.

In this policy the regional governments receive a transfer from the central government which reduces its provision of the government consumption goods equiproportionately to each region to maintain a balanced budget. The regional governments are allowed to spend the extra resources as they please and we assume that they choose the level of government consumption expenditure to maximise the welfare of the representative citizen while allowing infrastructure expenditure to adjust to satisfy their budget constraints. ${ }^{18}$ The immediate result in the short run is that both regional governments increase their provision of the consumption good to households by approximately the same proportion as the increase in transfers. In the interior region this less than exhausts the extra funds so that infrastructure spending is also increased while the opposite is the case in the coast - the transfer is insufficient to finance the extra consumption spending so that infrastructure spending must be curtailed. The change in infrastructure spending has an effect on regional output with interior output rising and coastal output falling. This drives a relative price change against agricultural output which, in turn, reduces income in the interior but raises it in the coast. The end result in the short run is that aggregate output, welfare and

\footnotetext{
${ }^{18}$ As noted in section 3, we assume different choice variables for the two maximising problems infrastructure spending for the empire-building case and consumption expenditure for the beneficent case. Simulations based on the alternative choice variable show that the conclusions we draw are not affected.
} 
income all increase but disparities in welfare and income worsen while the per capita output gap narrows. Hence the fiscal decentralisation is good for the country but not necessarily for regional disparities.

In the long run, labour migrates in response to welfare differences, hence moving from the interior to the coast. The increase in manufacturing employment in the coast more than offsets the short-run fall in output while falling employment in agriculture serves to reduce output. This latter is, however, partially offset by a further increase in infrastructure spending by the interior government made possible by the reduced demand for government consumption resulting from out-migration. The net effect is that there is a small reduction in agricultural output compared to the short run although it still rises relative to the initial equilibrium. At the aggregate level, output, income and welfare all rise, both relative to the short run and to the initial equilibrium. The welfare gap narrows as a result of migration but not by enough to offset the short-run widening; the same is true of the income gap between the regions.

Finally, given the widespread use of the expenditure ratio (DECEX in our model) in the empirical literature on decentralisation, it is interesting to consider the implications of our simulation results for the relationship between this ratio and decentralisation and also a number of summary measures. We present a summary in Table 2. A number of interesting points can be drawn from this table. First, DECEX always increases following decentralisation policy so that in this sense it is a satisfactory measure of decentralisation. Second, what, in general, does our model predict about the relationship between $D E C E X$ and welfare? The results in Table 2 suggest the following. (a) The empirical literature tests whether a rise in DECEX will improve welfare. Our results show there is no clear relationship between them since 
Policy 1 results in $D E C E X$ rising while welfare falls while $D E C E X$ and welfare move together for the other simulations. (b) Moreover, for the three cases in which welfare and DECEX move together, the magnitudes are not consistent - the largest rise in $D E C E X$ is associated with the smallest rises in welfare. We should not expect a tight empirical relationship between a summary measure such as $D E C E X$ and welfare or one of its proxies since the mechanism of decentralisation is important and this is not captured by a single-dimensional variable like $D E C E X$. (c) In all cases where $D E C E X$ and welfare mover together, the welfare gap worsens as a result of decentralisation decentralisation may improve welfare for the country as a whole but it masks a worsening of the geographical distribution of welfare. A third issue we can comment on using the results in Table 2 is whether the common practice of using output as a proxy for (unobservable) welfare in empirical work is justified. Our results suggest that it is and that income is also a suitable proxy since in all four simulations aggregate output, income and welfare move together. Moreover, the relative magnitudes of the movements are consistent across simulations.

\section{Conclusions}

This paper has considered the effects on a range of aggregate and regional variables of four different fiscal decentralisation policies. It has been shown that the effects of the policies differ considerably across different simulations. The nature of the effects was shown to depend crucially on how the regional governments react to an increase in resources. If it is assumed that the regional governments simply replace the reduced central government expenditure on the consumption good, the results are generally adverse since productive infrastructure spending is crowded out. If, on the other hand, the regional governments are allowed to spend the extra funds 
on infrastructure, there is effectively a substitution of infrastructure spending for consumption spending which improves aggregate welfare, income and output. A similar result obtains if we assume that the regional governments act strategically, either to maximise their budgets or to maximise the welfare of the representative citizen.

The effects of decentralisation on inter-regional disparities should be a matter of concern to the central government, however, since in most cases an improvement at the aggregate level masks a deterioration of the inter-regional distribution of resources.

Finally, our analysis has allowed us to throw light on some common practices in the empirical literature on decentralisation. First, a single-dimensional variable such as the ratio of regional to aggregate government expenditure is a good measure of decentralisation in the sense that in all four of our simulations it increased.

However, the measure is not closely related to the subsequent effect on welfare since this depends on the way in which the decentralisation is achieved and this cannot be taken into account in a summary measure. Thus, in one case welfare was actually reduced when the decentralisation measure increase. Moreover, even in the cases where summary measure and welfare moved together after a policy shock, the relative magnitudes did not match across simulations so that we should not expect a close empirical fit. Finally, we found that the common practice of using a proxy such as output or income instead of welfare is a reasonable one since they always moved together (both as to sign and magnitude) in our simulations. 
References

Bao, S., G. H. Chang, J. D. Sachs and W. T. Woo (2002) "Geographic Factors and China's Regional Development under Market Reforms, 1978-1998”, China Economic Review, 13, 89-111.

Boadway, R. and Flatters, F. (1982), "Efficiency and Equalisation Payments in a Federal System of Government: A Synthesis and Extension of Recent Results", Canadian Journal of Economics, 15, 613-633.

Bonet, J. (2006), "Fiscal Decentralization and Regional Income Disparities: Evidence from the Colombian Experience", Annals of Regional Science, 40, 661-672.

Brennan, G. and Buchanan, J.M. (1980), The Power to Tax-Analytical Foundations of a Fiscal Constitution, Cambridge: Cambridge University Press.

Brun, J.F., J. L. Combes and M. F. Renard (2002), "Are there Spillover Effects between the Coastal and Noncoastal Regions in China?", China Economic Review, 13, 161-169.

Buchanan, J. (1950), "Federalism and Fiscal Equity", American Economic Review, 40, $583-599$.

Calamai, L. (2009), "The Link between Devolution and Regional Disparities: Evidence from the Italian Regions", Environment and Planning A, 41, 11291151.

Canaleta, C. G., P. P. Arzoz and M. R. Garate (2004), "Regional Economic Disparities and Decentralization", Urban Studies, 41, 71-94.

Cantarero, D. and P. P. Gonzalez (2009), "Fiscal Decentralization and Economic Growth: Evidence from Spanish Regions", Public Budgeting and Finance, 29, 24-44.

Cheng, T. and Selden, M. (1994), "The Origins and Consequences of China's Hukou System", The China Quarterly, 139, 644-668.

Demurger, S. (2001), "Infrastructure Development and Economic Growth: An Explanation for Regional Disparities in China?", Journal of Comparative Economics, 29, 95-117.

Ding, Y, (2007), "Fiscal Decentralization and Economic Growth in China, 19942002", Journal of Chinese Economic and Business Studies, 5, 243-260.

Ezcurra, R. and P. Pascual (2008), "Fiscal Decentralization and Regional Disparities: Evidence from Several European Union Countries", Environment and Planning A, 40, 1185-1201.

Fan, S. (1991), "Effects of Technological Change and Institutional Reform on Production Growth in Chinese Agriculture", American Journal of Agricultural Economics, 73, 266-275.

Feltenstein, A. and S. Iwata (2005), "Decentralization and Macroeconomic Performance in China: Regional Autonomy has its Costs", Journal of Development Economics, 76, 481-501.

Fleisher, B. M and J. Chen (1997), "The Coast-Noncoast Income Gap, Productivity and Regional Economic Policy in China", Journal of Comparative Economics, 25, 220-236.

Fujita, M. and Hu, D. (2001), "Regional disparity in China 1985-1994: The effects of globalization and liberalization", Annals of Regional Science, 35, 3-37.

Groenewold, N., A Chen and G. Lee (2008), Linkages between China's Regions: Measurement and Policy, Edward Elgar, Cheltenham, UK. 
Groenewold, N., Hagger, A. J. and Madden, J. R. (2000), "Competitive Federalism: A Political-Economy General Equilibrium Approach”, Australasian Journal of Regional Science, 6, 451-465.

Groenewold, N., Hagger, A. J. and Madden, J. R. (2003), "Interregional Transfers: A Political-Economy CGE Approach”, Papers in Regional Science, 82, 535-554.

Groenewold, N. and Hagger, A. J. (2005), "The Effects of an Inter-Regional Transfer with Empire-Building Regional Governments", Review of Regional Studies, 35, 38-63.

Groenewold, N. and Hagger, A. J. (2007), "The Effects of Fiscal Equalisation in a Model with Endogenous Regional Governments: An Analysis in a TwoRegion Numerical Model", Annals of Regional Science, 41, 353-374.

Gutman, G. O. (1957), "A Note on Economic Development with Subsistence Agriculture", Oxford Economic Papers, 9, 323-334.

Hammond. G. W. and M. S. Tosun (2011), "The Impact of Ocal Decentralization on Economic growth: Evidence from US Counties", Journal of Regional Science, 51, 47-64.

He, C., Wei, Y. D. and X. Xie (2008), 'Globalization, Institutional Change, and Industrial Location: Economic Transition and Industrial Concentration in China', Regional Studies, 42, 923-945.

Hu, D.(2002), "Trade, Rural-Urban Migration, and Regional Income Disparity in Developing Countries: A Spatial General Equilibrium Model Inspired by the Case of China", Regional Science and Urban Economics, 32, 311-338.

Im, T. (2010), "Does Decentralization Reforms Always Increase Economic Growth? A Cross Country Comparison of Performance:, International Journal of Public Administration, 33, 508-520.

Jin, H., Qian, Y. and Weingast, B. R. (2005), "Regional Decentralization and Fiscal Incentives: Federalism Chinese Style", Journal of Public Economics, 89, 1719-1742.

Jin, J. and H. Zou (2005), “ Fiscal Decentralization, Revenue and Expenditure Assignments and Growth in China”, Journal of Asian Economics, 16, 10471064.

Kim, E., S. W. Hong and S. J. Ha (2003), "Impacts of national Development and Decentralization on Regional Income Disparity in Korea", Annals of Regional Science, 37, 79-91.

Krugman, P. R. (1991),”Increasing Returns and Economic Geography”, Journal of Political Economy, 99, 483-99.

Lessmann, C. (2009), "Fiscal Decentralization and Regional Disparity: Evidence from Cross-Section and Panel Data", Environment and Planning A, 41, 2455-2473.

Lewis, W. A. (1954), "Economic Development with Unlimited Supplies of Labour", Manchester School of Economic and Social Studies, 22, 139-191.

Li, C. (2010), "Savings, Investment and Capital Mobility within China", China Economic Review, 21, 14-23.

Lin J.Y., Wang G. and Zhao, Y.(2004), "Regional Inequality and Labor Transfers in China", Economic Development and Cultural Change, 52, 587-603.

Lin, J. Y. and Z. Liu (2000), "Fiscal Decentralization and Economic Growth in China", Economic Development and Cultural Change, 49, 1-21.

Liu, Z. (2005), "Institution and Inequality: The Hukou System in China", Journal of Comparative Economics, 33, 133-157.

Ma, Jun.(1997), “China's Fiscal Reform: An Overview”, Asian Economic Journal, 11, 443-458. 
Mansoorian, A. and Myers, G.M.(1993), “Attachment to Home and Efficient Purchases of Population in a Fiscal Externality Economy", Journal of Public Economics, 52, 117-132.

Mansur, A., Whalley, J.(1984), "Numerical Specification of Applied General Equilibrium Models: Estimation, Calibration and Data", in Scarf, H.E. and Shoven, J.B. (eds.) Applied General Equilibrium Analysis, Cambridge University Press, Cambridge.

Martinez-Vazquez, J. and R. M. McNab (2003), "Fiscal Decentralization and Economic Growth", World Development, 31, 1597-1616.

Martinez-Vazquez, J. and A. Timofeev (2010), "Decentralization Measures Revisited", Public Finance and Management, 10, 13-47.

McLure, C. E. (1995), "Comment on 'The Dangers of Fiscal Decentralization' by Prud'homme", World Bank Research Observer, 10, 221-226.

Mellor, J. W. and Stevens, R. D. (1956), "The Average and Marginal Product of Farm Labor in Underdeveloped Economies", Journal of Farm Economics, 38, 780791.

Musgrave R. (1959), The Theory of Public Finance, New York: McGraw Hill.

Myers, G. M. (1990), "Optimality, Free Mobility and the Regional Authority in a Federation", Journal of Public Economics, 43, 107-121.

Oates, W.E. (1972), Fiscal Federalism. New York: Harcourt Brace Jovanovich.

Oates, W.E. (2005), "Toward A Second-Generation Theory of Fiscal Federalism", Journal of International Tax and Public Finance, 12, 349-373.

Olson, M. (1969), "The Principle of 'Fiscal Equivalence: The Division of Responsibilities among Different Levels of Government”, American Economic Review, 59, 479-487.

Petchey, J. (1993), "Equalisation in a Federal Economy with Inter-State Migration and Different Factor Endowments", Australian Economic Papers, 32, 343-353.

Petchey, J. (1995), "Resource Rents, Cost Differences and Fiscal Equalization", Economic Record, 71, 343-353.

Petchey, J. and Shapiro, P. (2000), "The Efficiency of State Taxes on Mobile Labour Income", Economic Record, 76, 285-296.

Pissarides, C.A. and I. McMaster (1990), "Regional Migration, Wages and Unemployment: Empirical Evidence and Implications for Policy", Oxford Economic Papers, 42, 812-831.

Prud'homme, R. (1995), "The Dangers of Decentralization”, World Bank Research Observer, 10, 201-220.

Qiao, B, J. Martinez-Vazquez and Y. Xu (2008), "The Trade-Off between Growth and Equity in Decentralization Policy: China's Experience", Journal of Development Economics, 86, 112-128.

Rey, D. (1998), Development Economics, Princeton University Press, Princeton, NJ.

Robinson, W. C. (1971), "The Economics of Work Sharing in Peasant Agriculture", Economic Development and Cultural Change, 20, 131-141.

Rodriguez-Pose, A. and R. Ezcurra (2010), "Does Decentralization Matter for Regional Disparities? A Cross-Country Analysis", Journal of Economic Geography, 10, 619-644.

Rodriguez-Pose, A. and A. Kroijer (2009), "Fiscal Decentralization and Economic Growth in Central and Eastern Europe", Growth and Change, 2009, 40, 387417.

Rodriguez-Pose, A., S. A. R. Tijmstra and A. Bwire (2009), "Fiscal Decentralisation, Efficiency and Growth”, Environment and Planning A, 41, 2041-2062. 
Samuelson, P. A. (1954), "The pure theory of public expenditure”, Review of Economics and Statistics 36, 387-389.

Scott, D. (1950), "A Note on Grants in Federal Countries", Economica, 17(68): 416422.

Shen, C., Jin, J. and Zou, H. (2006), "Fiscal Decentralization in China: History, Impacts, Challenges and Next Steps", World Bank Discussion Paper.

State Statistical Bureau (2005), China Civil Affairs Statistical Yearbook 2005, Statistical Publishing House of China, Beijing.

State Statistical Bureau (various issues), Statistical Yearbook of China, Statistical Publishing House of China, Beijing.

Tiebout, C. (1956), “A Pure Theory of Local Expenditure”, Journal of Political Economy, 64, 416-424.

Tochkov, K. (2007), "Interregional Transfers and the Smoothing of Provincial Expenditure in China", China Economic Review, 18, 54-65.

Vo, D. (2010), “The Economics of Fiscal Decentralization", Journal of Economic Surveys, 24, 657-679.

Wagner, R. (2007), Fiscal Sociology and the Theory of Public Finance: An Exploratory Essay, Cheltenham: Edward Elgar.

Whalley, J. and Zhang, S. (2007), "A Numerical Simulation Analysis of (Hukou) Labour Mobility Restrictions in China", Journal of Development Economics, 83, 392-410.

Woodland, A.D. and Yoshida, C.(2006), "Risk Preference, Immigration Policy and Illegal Immigration”, Journal of Development Economics, 81, 500- 513.

Yusuf, S. (1994), "China's Macroeconomic Performance and Management During Transition", Journal of Economic Perspectives, 8, 71-92.

Zhang, T. and H.-F. Zou (1998), "Fiscal Decentralization, Public Spending and Economic Growth in China", Journal of Public Economics, 67, 221-240.

Zhang, T. and H.-F. Zou (2001), "The Growth Impact of Intersectoral and Intergovernmental Allocation of Public Expenditure: With Applications to China and India", China Economic Review, 12, 58-81.

Zhang, X. (2006), "Fiscal Decentralization and Political Centralization in China: Implications for Growth and Inequality", Journal of Comparative Economics, 34, 713-726.

Zhang, Z. and Martinez-Vazquez, J. (2003), "The System of Equalizing Transfers in China”, International Studies Program Working Paper 03-12, Andrew Young School of Policy Studies, Georgia State University. 
Figure 1. Evolution of government expenditure and revenue

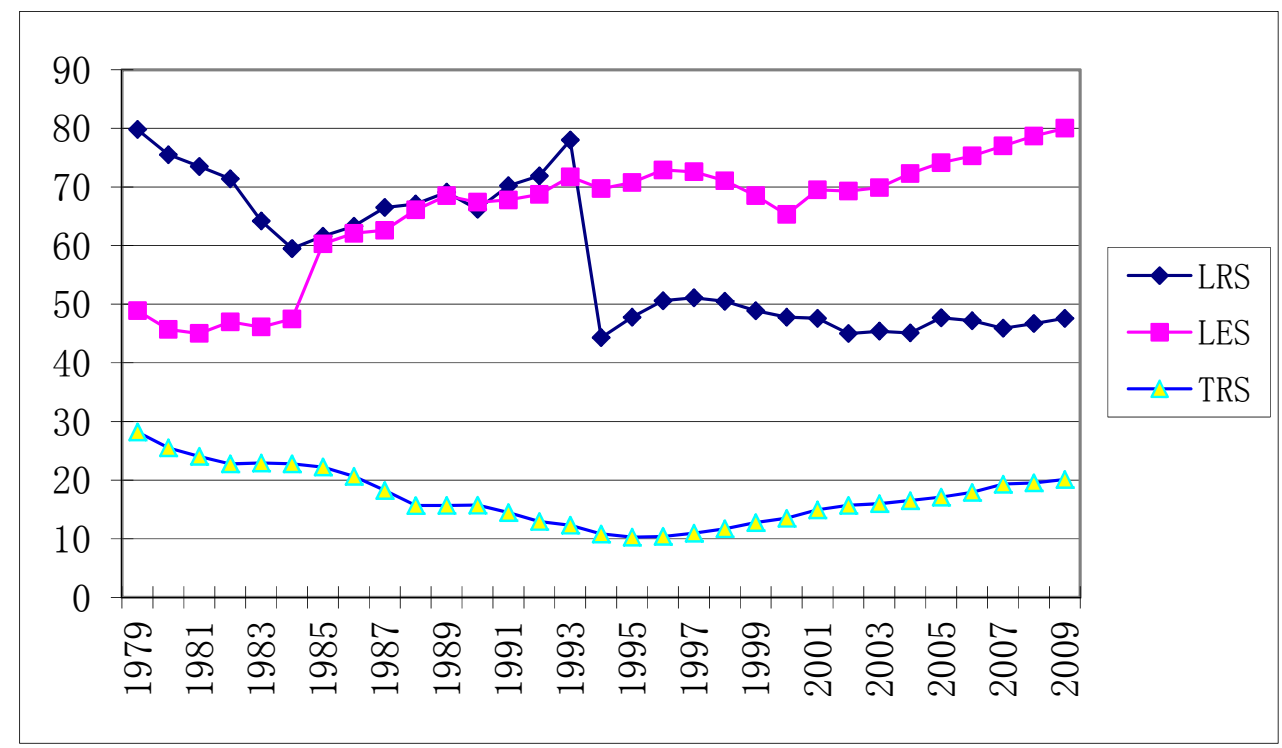

Notes: "LRS" is the local government share of total revenue (\%)," LES" is the local government share in total expenditure (\%), and "TRS" is the ratio of total revenue to GDP (\%).

Source: China Statistical Year Book (NSB, various issues)

Figure 2. Growth and disparities

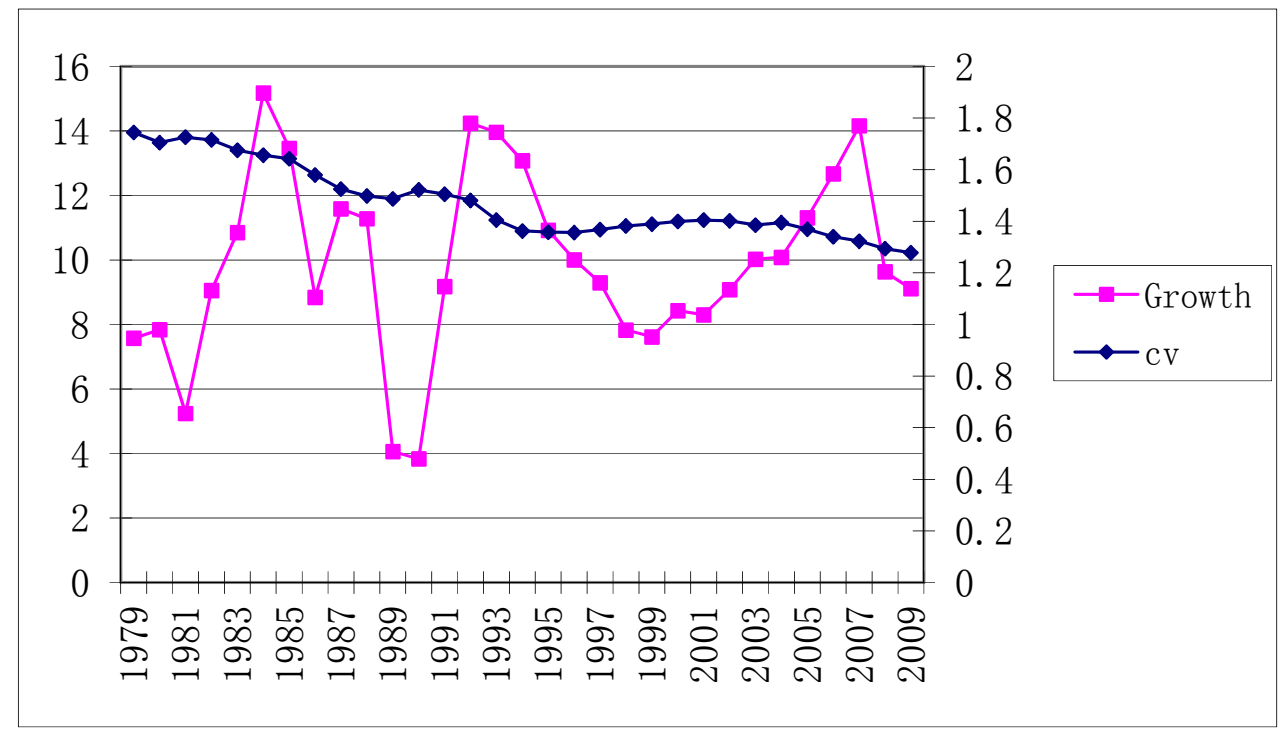

Notes: "cv" is the coefficients of variation of GDP per capita across the provinces; "Growth" is the real GDP growth rate (\% pa).

Source: China Statistical Year Book (NSB, various issues) 
Figure 3. The two regions of mainland China

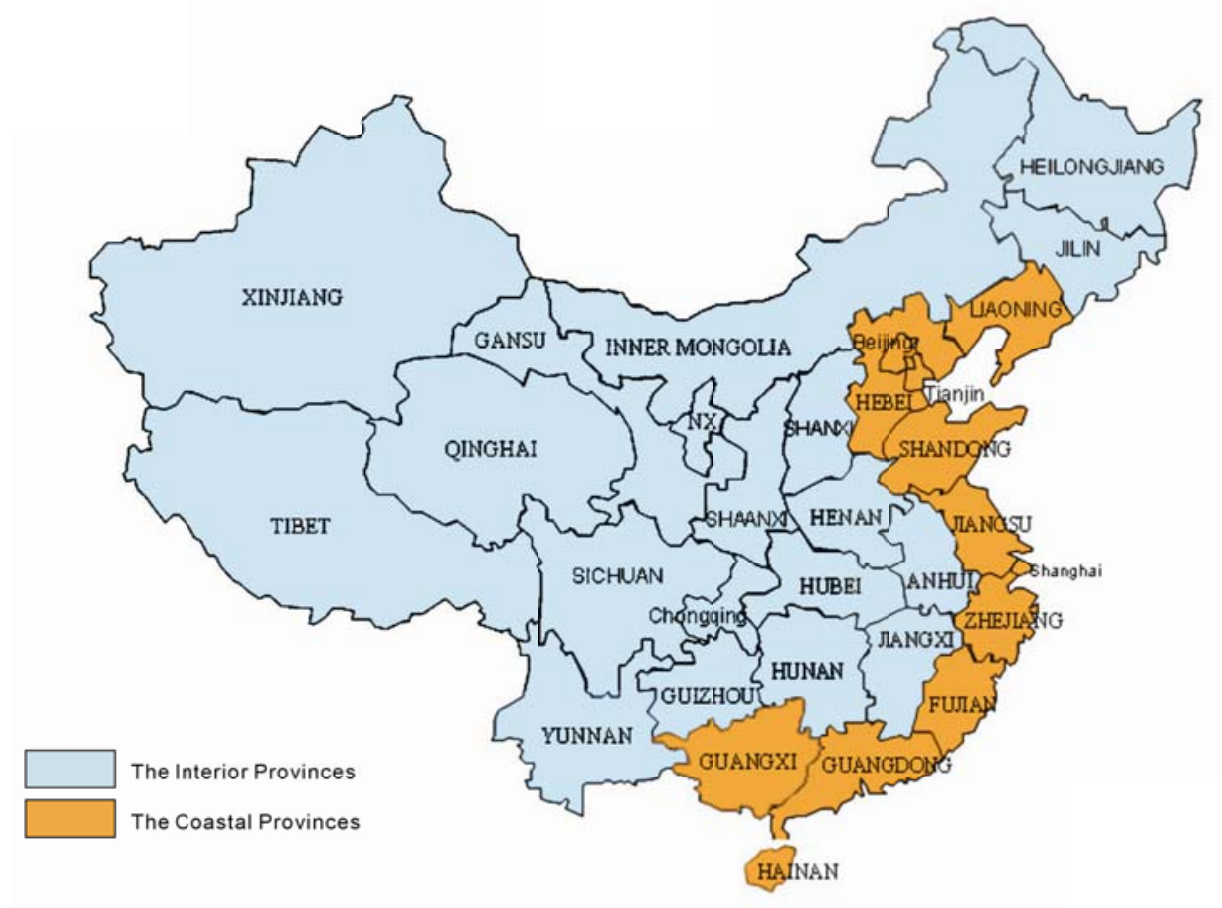


Table 1. Simulation results

\begin{tabular}{|c|c|c|c|c|c|c|c|c|}
\hline \multirow[b]{2}{*}{ Variable } & \multicolumn{2}{|c|}{ Policy 1} & \multicolumn{2}{|c|}{ Policy 2} & \multicolumn{2}{|c|}{ Policy 3} & \multicolumn{2}{|c|}{ Policy 4} \\
\hline & $\mathrm{SR}$ & LR & SR & $\mathrm{LR}$ & $\mathrm{SR}$ & $\mathrm{LR}$ & $\mathrm{SR}$ & $\mathrm{LR}$ \\
\hline$v_{I}$ & 0.0476 & 0.0161 & -0.0198 & 0.0945 & -0.0198 & 0.0971 & -0.0506 & 0.0073 \\
\hline$v_{C}$ & -0.0394 & -0.0171 & 0.3020 & 0.2524 & 0.3020 & 0.2358 & 0.1068 & 0.0691 \\
\hline$v$ & -0.0195 & -0.0211 & 0.2285 & 0.2711 & 0.2285 & 0.2523 & 0.0708 & 0.0765 \\
\hline$c_{A I}$ & 0.0000 & -0.0225 & 0.2292 & 0.3437 & 0.2292 & 0.3296 & 0.0124 & 0.0568 \\
\hline$c_{M I}$ & 0.0000 & -0.0411 & -0.0847 & 0.0630 & -0.0847 & 0.0676 & -0.1339 & -0.0581 \\
\hline$c_{A C}$ & 0.0000 & 0.0346 & 0.6287 & 0.5432 & 0.6287 & 0.5242 & 0.1985 & 0.1411 \\
\hline$c_{M C}$ & 0.0000 & 0.0159 & 0.3148 & 0.2624 & 0.3148 & 0.2623 & 0.0522 & 0.0263 \\
\hline$g h_{I}$ & 0.2661 & 0.2361 & -0.4439 & -0.4064 & -0.4439 & -0.3697 & -0.0048 & 0.0433 \\
\hline$g h_{C}$ & -0.2589 & -0.2429 & -0.4693 & -0.4296 & -0.4693 & -0.4960 & 0.0850 & 0.0520 \\
\hline$j_{I}$ & 0.0000 & -0.0348 & 0.0220 & 0.1584 & 0.0220 & 0.1566 & -0.0842 & -0.0191 \\
\hline$j_{C}$ & 0.0000 & 0.0246 & 0.4617 & 0.3938 & 0.4617 & 0.3849 & 0.1207 & 0.0800 \\
\hline$j$ & 0.0000 & -0.0062 & 0.2661 & 0.3097 & 0.2661 & 0.3015 & 0.0295 & 0.0440 \\
\hline$\pi h_{I}$ & 0.0000 & -0.0106 & 0.4286 & 0.5221 & 0.4286 & 0.4960 & 0.1053 & 0.1297 \\
\hline$\pi h_{C}$ & 0.0000 & 0.0064 & 0.1550 & 0.1195 & 0.1550 & 0.1290 & -0.0222 & -0.0322 \\
\hline$w_{A}$ & 0.0000 & -0.0106 & 0.4286 & 0.5221 & 0.4286 & 0.4960 & 0.1053 & 0.1297 \\
\hline$w_{M}$ & 0.0000 & 0.0064 & 0.1550 & 0.1195 & 0.1550 & 0.1290 & -0.0222 & -0.0322 \\
\hline$y_{A}$ & 0.0000 & 0.0035 & 0.4286 & 0.4551 & 0.4286 & 0.4371 & 0.1053 & 0.1035 \\
\hline$y_{M}$ & 0.0000 & -0.0128 & 0.1550 & 0.2104 & 0.1550 & 0.2088 & -0.0222 & 0.0034 \\
\hline$y$ & 0.0000 & -0.0058 & 0.2727 & 0.3156 & 0.2727 & 0.3070 & 0.0326 & 0.0464 \\
\hline$l_{A}$ & 0.0000 & 0.0141 & 0.0000 & -0.0670 & 0.0000 & -0.0588 & 0.0000 & -0.0262 \\
\hline$l_{M}$ & 0.0000 & -0.0192 & 0.0000 & 0.0909 & 0.0000 & 0.0799 & 0.0000 & 0.0356 \\
\hline$y_{A}-l_{A}$ & 0.0000 & -0.0106 & 0.4286 & 0.5221 & 0.4286 & 0.4960 & 0.1053 & 0.1297 \\
\hline$y_{M}-l_{M}$ & 0.0000 & 0.0064 & 0.1550 & 0.1195 & 0.1550 & 0.1290 & -0.0222 & -0.0322 \\
\hline$\pi f_{A}$ & 0.0000 & 0.0035 & 0.4286 & 0.4551 & 0.4286 & 0.4371 & 0.1053 & 0.1035 \\
\hline$\pi f_{M}$ & 0.0000 & -0.0128 & 0.1550 & 0.2104 & 0.1550 & 0.2088 & -0.0222 & 0.0034 \\
\hline$p$ & 0.0000 & -0.0425 & -0.7134 & -0.6381 & -0.7134 & -0.5953 & -0.3323 & -0.2610 \\
\hline$g r h_{I}$ & 1.2859 & 1.2525 & 0.0000 & 0.0000 & 0.0000 & 0.0588 & 0.8865 & 0.9345 \\
\hline$g r f_{A}$ & 0.0000 & 0.0000 & 1.0716 & 1.1797 & 1.0716 & 1.1296 & 0.2631 & 0.2751 \\
\hline$g r h_{C}$ & 0.6499 & 0.6789 & 0.0000 & 0.0000 & 0.0000 & -0.0799 & 1.0783 & 1.0157 \\
\hline $\operatorname{grf}_{M}$ & 0.0000 & 0.0000 & 1.0234 & 0.9891 & 1.0234 & 1.0272 & -0.1466 & -0.1342 \\
\hline$g c_{I}$ & -2.7653 & -2.7852 & -1.7634 & -1.6143 & -1.7634 & -1.6435 & -2.6541 & -2.6055 \\
\hline$g c_{C}$ & -2.7653 & -2.7852 & -1.7634 & -1.6143 & -1.7634 & -1.6435 & -2.6541 & -2.6055 \\
\hline decex & 0.4145 & 0.4172 & 0.3077 & 0.2892 & 0.3077 & 0.2924 & 0.4038 & 0.3975 \\
\hline$t r_{I}$ & 1.0000 & 1.0000 & 1.0000 & 1.0000 & 1.0000 & 1.0000 & 1.0000 & 1.0000 \\
\hline$t r_{C}$ & 1.0000 & 1.0000 & 1.0000 & 1.0000 & 1.0000 & 1.0000 & 1.0000 & 1.0000 \\
\hline
\end{tabular}

Notes: (1) All policies involve an equal unit proportional change in transfers from the central to the regional government; Policy 1 assumes regional governments adjust their consumption expenditure, Policy 2 assumes the regional governments adjust their infrastructure expenditure, Policy 3 assumes that regional governments act to maximise their budget and Policy 4 assumes that regional governments act to maximise the welfare of their representative citizen; (2) since $y_{j}$ and $l_{j}$ are $\log$ differences of output and population respectively, $y_{j}-l_{j}$ is the $\log$ difference of output per capita; (3) not all variable in the model are listed in the table. 
Table 2: Summary of long-run effects

\begin{tabular}{|l|c|c|c|c|}
\hline Variable & Policy 1 & Policy 2 & Policy 3 & Policy 4 \\
\hline welfare & -0.0211 & 0.2711 & 0.2523 & 0.0765 \\
\hline income & -0.0062 & 0.3097 & 0.3015 & 0.0440 \\
\hline output & -0.0058 & 0.3156 & 0.3070 & 0.0464 \\
\hline$D E C E X$ & 0.4172 & 0.2892 & 0.2924 & 0.3975 \\
\hline welfare gap & narrows & widens & widens & widens \\
\hline income gap & widens & widens & widens & widens \\
\hline p. c. output gap & widens & narrows & narrows & narrows \\
\hline
\end{tabular}

Note: All policies involve an equal unit proportional change in transfers from the central to the regional government; Policy 1 assumes regional governments adjust their consumption expenditure, Policy 2 assumes the regional governments adjust their infrastructure expenditure, Policy 3 assumes that regional governments act to maximise their budget and Policy 4 assumes that regional governments act to maximise the welfare of their representative citizen. 
Appendix 1: Definition of variables

$V_{i}=$ utility of the representative household, region $i$

$V=$ national welfare

$C_{A i}=$ real private consumption of agricultural output per household, region $i$

$C_{M i}=$ real private consumption of manufactured good per household, region $i$

$G H_{i}=$ real government-provided consumption per household, region $i$.

$P=$ price of agricultural good in terms of manufactured good

$J_{i}=$ real household income (net of VAT), region $i$

$J=$ national income

$W_{j}=$ real wage income, sector $j$

$\Pi H_{i}=$ real profit distribution per household, region $i$

$D_{j}=$ productivity parameter, sector $j$

$Y_{j}=$ real output, sector $j$

$Y=$ national output,

$L_{j}=$ employment, sector $j$

$L=$ national employment

$\Pi F_{j}=$ firm profit, sector $j$

$T_{v}=$ value added tax rate

$T_{j}=$ output tax rate, sector $j$

$T R_{i}=$ lump-sum transfer from the central government to regional government $i$

$G R H_{i}=$ real regional government-provided consumption good per household, region $i$

$G R F_{i}=$ real regional government-provided public good, region $i$

$G C_{i}=$ real central government-provided consumption good per household in region $i$

$\theta=$ share of valued tax to the central government

$D E C E X=$ the regional share of aggregate government expenditure

$\mu=$ hukou parameter 
Appendix 2: Linearised version of the model

The model of section 3 is linearised in terms of proportional differences by taking logarithms and differentials of each equation. The linearised form of equations (1) to (19) (excluding equations (16) which are redundant) of the model are as follows, with the linearised form having the same number as the original equation but being distinguished by a prime.

The linearised utility function is:

(1') $v_{i}=\sigma_{\text {caiv }} c_{A i}+\sigma_{\text {cmiv }} c_{M i}+\sigma_{\text {ghiv }} g h_{i}$

where lower-case letters represent the proportional changes (log differential) of their upper-case counterparts and

$$
\begin{aligned}
\sigma_{\text {caiv }} & =\frac{\gamma_{A i} C_{A i}^{-\rho}}{\gamma_{A i} C_{A i}^{-\rho}+\gamma_{M i} C_{M i}^{-\rho}+\delta_{i} G H_{i}^{-\rho}}, \\
\sigma_{c m i v} & =\frac{\gamma_{M i} C_{M i}^{-\rho}}{\gamma_{A i} C_{A i}^{-\rho}+\gamma_{M i} C_{M i}^{-\rho}+\delta_{i} G H_{i}^{-\rho}}, \\
\sigma_{\text {ghiv }} & =\frac{\delta_{i} G H_{i}^{-\rho}}{\gamma_{A i} C_{A i}^{-\rho}+\gamma_{M i} C_{M i}^{-\rho}+\delta_{i} G H_{i}^{-\rho}} .
\end{aligned}
$$

The linearised consumption demand functions are:

$$
\text { (2a') } c_{A i}=j_{i}+\lambda p-\sigma_{\text {cai }} p-\sigma_{\text {elas }} p \quad i=I, C
$$

where $\sigma_{c a i}=\frac{\frac{\rho}{\rho+1}}{1+P^{\frac{-\rho}{\rho+1}}\left(\frac{\gamma_{M i}}{\gamma_{A i}}\right)^{\frac{1}{\rho+1}}}, \sigma_{\text {elas }}=\frac{1}{\rho+1}$, and

(2b') $c_{M i}=j_{i}+\lambda p-\sigma_{c a i} p$

The linearised definitions of real household income are:

(3a') $\sigma_{t v} t_{v}+j_{I}=(1-\lambda) p+\sigma_{\pi h j} \pi h_{I}+\sigma_{w j I} w_{I}$

where $\sigma_{\pi h j I}=\frac{\Pi H_{I}}{\Pi H_{I}+W_{I}}, \sigma_{w j I}=\frac{W_{I}}{\Pi H_{I}+W_{I}}, \sigma_{t v}=\frac{T_{v}}{1+T_{v}}$, and

(3b') $\sigma_{t v} t_{v}+j_{C}=-\lambda p+\sigma_{\pi h j C} \pi h_{C}+\sigma_{w j C} w_{C}$

where $\sigma_{\pi h j C}=\frac{\Pi H_{C}}{\Pi H_{C}+W_{C}}, \sigma_{w j C}=\frac{W_{C}}{I I H_{C}+W_{C}}$.

The linearised migration equilibrium condition corresponding to equation (4) is:

(4') $v_{C}=v_{I}+\mu^{*} \mu \log \left(\frac{L_{M} / A_{C}}{L_{A} / A_{I}}\right)+\mu\left(n_{C}-n_{I}\right)$

where $\mu^{*}=d \mu / \mu$ and we have used the obvious assumption that area is constant.

The linearised production functions are:

$$
y_{j}=d_{j}+\alpha_{j G} \operatorname{grf}_{j}+\alpha_{j L}\left(l_{j}-f_{j}\right) \quad j=A, M
$$

The linearised profit definitions are given by:

$$
\pi f_{j}=\sigma_{y \pi f j} y_{j}-\sigma_{t j} \sigma_{y \pi f j} t_{j}-\sigma_{w \pi f j}\left(w_{j}+l_{j}-f_{j}\right) \quad j=A, M
$$

where $\sigma_{y \pi f j}=\frac{\left(1-T_{j}\right) Y_{j}}{\Pi F_{j}}, \sigma_{t j}=\frac{T_{j}}{1-T_{j}}, \sigma_{w \pi f j}=\frac{W_{j}\left(L_{j} / F_{j}\right)}{\Pi F_{j}}$.

The manufacturing sector's profit-maximisation condition in linear form is: 
(7a') $w_{M}+\sigma_{t M} t_{M}-d_{M}-\alpha_{M G} g r f_{M}+\left(1-\alpha_{M L}\right)\left(l_{M}-f_{M}\right)=0$

and that for agriculture is given by:

(7b') $w_{A}+\sigma_{t A} t_{A}-d_{A}-\alpha_{A G} g r f_{A}+\left(1-\alpha_{A L}\right)\left(l_{A}-f_{A}\right)=0$.

The central government's budget constraint is linearised as:

$\left(8^{\prime}\right)$

$\sigma_{g c l g c}\left(l_{A}+g c_{I}\right)+\sigma_{g c C g c}\left(l_{M}+g c_{C}\right)+\sigma_{g c t r}\left(\sigma_{t r t r I} t r_{I}+\sigma_{t r t r C} t r_{C}\right)=\theta^{*}+t_{v}+\sigma_{j l j}\left(l_{A}+j_{I}\right)+\sigma_{j C j}\left(l_{M}+j_{C}\right)$

where $\sigma_{g c l g c}=\frac{L_{A} G C_{I}}{L_{A} G C_{I}+L_{M} G C_{C}+T R_{I}+T R_{C}}, \sigma_{g c C g c}=\frac{L_{M} G C_{C}}{L_{A} G C_{I}+L_{M} G C_{C}+T R_{I}+T R_{C}}$,

$\sigma_{g c t r}=\frac{T R_{I}+T R_{C}}{L_{A} G C_{I}+L_{M} G C_{C}+T R_{I}+T R_{C}}, \sigma_{j l j}=\frac{L_{A} J_{I}}{L_{A} J_{I}+L_{M} J_{C}}, \sigma_{j C j}=\frac{L_{M} J_{C}}{L_{A} J_{I}+L_{M} J_{C}}$,

$\theta^{*}=d \theta / \theta, \quad \sigma_{t r t r I}=\frac{T R_{I}}{T R_{I}+T R_{C}}, \quad \sigma_{t r t r C}=\frac{T R_{C}}{T R_{I}+T R_{C}}$.

The regional governments' budget constraints are linearised as:

(9a') $\sigma_{\text {grhlgr }}\left(l_{A}+g r h_{I}\right)+\sigma_{\text {grfAgr }} g r f_{A}-\sigma_{\text {grtrI }} t r_{I}$

$$
=\sigma_{t A g r}\left(f_{A}+t_{A}+p-\lambda p+y_{A}\right)+\sigma_{t v I g r}\left(-\sigma_{\theta} \theta^{*}+t_{V}+l_{A}+j_{I}\right)
$$

where $\sigma_{g r h l g r}=\frac{L_{A} G R H_{I}}{L_{A} G R H_{I}+G R F_{A}-T R_{I}}, \sigma_{g r f A g r}=\frac{G R F_{A}}{L_{A} G R H_{I}+G R F_{A}-T R_{I}}$,

$$
\begin{aligned}
\sigma_{g r t r I} & =\frac{T R_{I}}{L_{A} G R H_{I}+G R F_{A}-T R_{I}}, \sigma_{\theta}=\frac{\theta}{1-\theta}, \\
\sigma_{t A g r} & =\frac{F_{A} T_{A} P^{1-\lambda} Y_{A}}{F_{A} T_{A} P^{1-\lambda} Y_{A}+(1-\theta) T_{V} L_{A} J_{I}}, \sigma_{t v I g r}=\frac{(1-\theta) T_{V} N_{I} J_{I}}{F_{A} T_{A} P^{1-\lambda} Y_{A}+(1-\theta) T_{V} L_{A} J_{I}}, \text { and }
\end{aligned}
$$

(9b') $\sigma_{g r h C g r}\left(l_{M}+g r h_{C}\right)+\sigma_{g r m M g r} g r f_{M}-\sigma_{g r t r C} t r_{C}$

$$
=\sigma_{t M g r}\left(f_{M}+t_{M}-\lambda p+y_{M}\right)+\sigma_{t v C g r}\left(-\sigma_{\theta} \theta^{*}+t_{V}+l_{M}+j_{C}\right)
$$

where $\sigma_{g r h C g r}=\frac{L_{M} G R H_{C}}{L_{M} G R H_{C}+G R F_{M}-T R_{C}}, \sigma_{g r f M g r}=\frac{G R F_{M}}{L_{M} G R H_{C}+G R F_{M}-T R_{C}}$,

$$
\begin{aligned}
\sigma_{g r t r} & =\frac{T R_{C}}{L_{M} G R H_{C}+G R F_{M}-T R_{C}} \\
\sigma_{t M g r} & =\frac{F_{M} T_{M} P^{-\lambda} Y_{M}}{F_{M} T_{M} P^{-\lambda} Y_{M}+(1-\theta) T_{V} L_{M} J_{C}}, \sigma_{t v C g r}=\frac{(1-\theta) T_{V} L_{M} J_{C}}{F_{M} T_{M} P^{-\lambda} Y_{M}+(1-\theta) T_{V} L_{M} J_{C}}
\end{aligned}
$$

The definition of the decentralisation measure is linearised as:

$\left(10^{\prime}\right)$ decex $=\sigma_{\text {dergrf } A} \operatorname{grf}_{A}+\sigma_{\text {dergrhI }}\left(l_{A}+\operatorname{grh}_{I}\right)+\sigma_{\text {dergrf } M} g r f_{M}+\sigma_{\text {dergrhC }}\left(l_{M}+g h_{C}\right)$

$$
\begin{aligned}
& -\sigma_{\text {dengrf } A} g r f_{I \backslash A}-\sigma_{\text {dengrh } I}\left(l_{A}+g r h_{I}\right)-\sigma_{\text {dengrf } M} g r f_{M}-\sigma_{\text {dengrhC }}\left(l_{M}+g r h_{C}\right) \\
& -\sigma_{\text {dengc } I}\left(l_{A}+g c_{I}\right)-\sigma_{\text {dengc } C}\left(l_{M}+g c_{C}\right)
\end{aligned}
$$

where $\sigma_{\text {dergrff }}=\frac{G R F_{A}}{G R F_{A}+L_{A} G R H_{I}+G R F_{M}+L_{M} G R H_{C}}$

$\sigma_{\text {dergrhI }}=\frac{L_{A} G R H_{I}}{G R F_{A}+L_{A} G R H_{I}+G R F_{M}+L_{M} G R H_{C}}$

$\sigma_{\text {dergrfm }}=\frac{G R F_{M}}{G R F_{A}+L_{A} G R H_{I}+G R F_{M}+L_{M} G R H_{C}}$ 


$$
\begin{aligned}
\sigma_{\text {dergrhC }} & =\frac{L_{M} G R H_{C}}{G R F_{A}+L_{A} G R H_{I}+G R F_{M}+L_{M} G R H_{C}} \\
\sigma_{\text {dengrfa }} & =\frac{G R F_{A}}{G R F_{A}+L_{A} G R H_{I}+G R F_{M}+L_{M} G R H_{C}+L_{A} G C_{I}+L_{M} G C_{C}} \\
\sigma_{\text {dengrhI }} & =\frac{L_{A} * G R H_{I}}{G R F_{A}+L_{A} G R H_{I}+G R F_{M}+L_{M} G R H_{C}+L_{A} G C_{I}+L_{M} G C_{C}} \\
\sigma_{\text {dengrfM }} & =\frac{G R F_{M}}{G R F_{A}+L_{A} G R H_{I}+G R F_{M}+L_{M} G R H_{C}+L_{A} G C_{I}+L_{M} G C_{C}} \\
\sigma_{\text {dengrhC }}= & \frac{L_{M} G R H_{C}}{G R F_{A}+L_{A} G R H_{I}+G R F_{M}+L_{M} G R H_{C}+L_{A} G C_{I}+L_{M} G C_{C}} \\
\sigma_{\text {dengcl }}= & \frac{L_{A} G C_{I}}{G R F_{A}+L_{A} G R H_{I}+G R F_{M}+L_{M} G R H_{C}+L_{A} G C_{I}+L_{M} G C_{C}} \\
\sigma_{\text {dengcC }}= & \frac{L_{M} G C_{C}}{G R F_{A}+L_{A} G R H_{I}+G R F_{M}+L_{M} G R H_{C}+L_{A} G C_{I}+L_{M} G C_{C}}
\end{aligned}
$$

The linearised equations for the empire building assumption:

(11a') $\sigma_{n g r h l} l_{A}=-\sigma_{\text {grhI }}$ grh $_{I}$

(11b") $\sigma_{n g r h C} l_{M}=-\sigma_{g r h C} g r h_{C}$

$$
\begin{gathered}
\text { where } \sigma_{n g r h I}=\frac{L_{A} \frac{\partial G R H_{I}}{\partial G R F_{A}}}{L_{A} \frac{\partial G R H_{I}}{\partial G R F_{A}}+G R H_{I} \frac{\partial L_{A}}{\partial G R F_{A}}}, \sigma_{g r h I}=\frac{G R H_{I} \frac{\partial L_{A}}{\partial G R F_{A}}}{L_{A} \frac{\partial G R H_{I}}{\partial G R F_{A}}+G R H_{I} \frac{\partial L_{A}}{\partial G R F_{A}}} \\
\sigma_{n g r h C}=\frac{L_{M} \frac{\partial G R H_{C}}{\partial G R F_{M}}}{L_{M} \frac{\partial G R H_{C}}{\partial G R F_{M}}+G R H_{C} \frac{\partial L_{M}}{\partial G R F_{M}}}, \sigma_{g r h C}=\frac{G R H_{C} \frac{\partial L_{M}}{\partial G R F_{M}}}{L_{M} \frac{\partial G R H_{C}}{\partial G R F_{M}}+G R H_{C} \frac{\partial L_{M}}{\partial G R F_{M}}}
\end{gathered}
$$

(11c") $g h_{I}=\sigma_{G H M I} c_{M I}+\sigma_{G H A I} c_{A I}$

(11d') $g h_{C}=\sigma_{G H M C} c_{M C}+\sigma_{G H A C} c_{A C}$

$$
\begin{gathered}
\text { where } \sigma_{G H M I}=\frac{\gamma_{M I} \frac{\partial C_{M I}}{C_{M I}} / \frac{\partial G R H_{I}}{G R H_{I}} C_{M I}^{-\rho}}{\gamma_{M I} \frac{\partial C_{M I}}{C_{M I}} / \frac{\partial G R H_{I}}{G R H_{I}} C_{M I}^{-\rho}+\gamma_{A I} \frac{\partial C_{A I}}{C_{A I}} / \frac{\partial G R H_{I}}{G R H_{I}} C_{A I}^{-\rho}} \\
\sigma_{G H A I}=\frac{\gamma_{A I} \frac{\partial C_{A I}}{C_{A I}} / \frac{\partial G R H_{I}}{G R H_{I}} C_{A I}^{-\rho}}{\gamma_{M I} \frac{\partial C_{M I}}{C_{M I}} / \frac{\partial G R H_{I}}{G R H_{I}} C_{M I}^{-\rho}+\gamma_{A I} \frac{\partial C_{A I}}{C_{A I}} / \frac{\partial G R H_{I}}{G R H_{I}} C_{A I}^{-\rho}} \\
\sigma_{G H M C}=\frac{\gamma_{M C} \frac{\partial C_{M C}}{C_{M C}} / \frac{\partial G R H_{C}}{G R H_{C}} C_{M C}^{-\rho}}{\gamma_{M C} \frac{\partial C_{M C}}{C_{M C}} / \frac{\partial G R H_{C}}{G R H_{C}} C_{M C}^{-\rho}+\gamma_{A C} \frac{\partial C_{A C}}{C_{A C}} / \frac{\partial G R H_{C}}{G R H_{C}} C_{A C}^{-\rho}}
\end{gathered}
$$




$$
\sigma_{G H A C}=\frac{\gamma_{A C} \frac{\partial C_{A C}}{C_{A C}} / \frac{\partial G R H_{C}}{G R H_{C}} C_{A C}^{-\rho}}{\gamma_{M C} \frac{\partial C_{M C}}{C_{M C}} / \frac{\partial G R H_{C}}{G R H_{C}} C_{M C}^{-\rho}+\gamma_{A C} \frac{\partial C_{A C}}{C_{A C}} / \frac{\partial G R H_{C}}{G R H_{C}} C_{A C}^{-\rho}}
$$

The definition of national output is linearised as:

(12') $y=\sigma_{y y A}\left(f_{A}+y_{A}\right)+\sigma_{y y M}\left(f_{M}+y_{M}\right)$

where $\sigma_{y y A}=\frac{Y_{A}}{Y_{A}+Y_{M}}, \sigma_{y y M}=\frac{Y_{M}}{Y_{A}+Y_{M}}$ and we assume that $\lambda=\sigma_{y y A}$.

The definition of national income is linearised as:

(13') $j=\sigma_{n l j}\left(j_{I}+l_{A}\right)+\sigma_{n C j}\left(j_{C}+l_{M}\right)$

where $\sigma_{n l j}=\frac{L_{A} J_{I}}{L_{A} J_{I}+L_{M} J_{C}}, \sigma_{n C j}=\frac{L_{M} J_{C}}{L_{A} J_{I}+L_{M} J_{C}}$.

The definition of national welfare is linearised as:

(14') $v=\sigma_{n V}\left(v_{I}+l_{A}-n\right)+\sigma_{n C v}\left(v_{C}+l_{M}-n\right)$

where $\sigma_{n V v}=\frac{L_{A} V_{I}}{L_{A} V_{I}+L_{M} V_{C}}, \sigma_{n C v}=\frac{L_{M} V_{C}}{L_{A} V_{I}+L_{M} V_{C}}$.

The definition of $G H_{i}$ is linearised as:

(15') $g h_{i}=\sigma_{\text {grhigh }} g r h_{i}+\sigma_{\text {gcigh }} g c_{i}$

where $\sigma_{\text {grhigh }}=\frac{G R H_{i}}{G H_{i}}, \sigma_{\text {gcigh }}=\frac{G C_{i}}{G H_{i}}$.

Equations (16), the goods markets clearing conditions, are dropped from the model due to the redundancy result explained in section 3 .

The profit distribution conditions can be linearised to give:

(17a') $f_{A}+\pi f_{A}=l_{A}+\pi h_{I}$,

(17b') $f_{M}+\pi f_{M}=l_{M}+\pi h_{C}$.

The balance of trade condition in linear form is:

(18') $l_{M}+p+c_{A C}=l_{A}+c_{M I}$.

The national employment constraint results in the following linearised condition:

(19') $\sigma_{n I} l_{A}+\sigma_{n C} l_{M}=l$

where $\sigma_{n I}=L_{A} / L, \sigma_{n C}=L_{M} / L$. 
Appendix 3: Calibrating the linearised model

The linearised model contains a number of parameters which have to be evaluated before the model can be put to work to simulate the effects of various shocks. These parameters fall into two groups. The first are parameters which appear in model relationships; $\gamma_{j i}, \delta_{i}$ and $\rho$ appear in the utility function (1) and $\alpha_{j G}$ and $\alpha_{j L}$ appear in the production function (5). The remainder, on the other hand, are linearisation parameters which are all shares of some sort.

The model parameters were evaluated as follows. For the parameters of the utility function we broadly followed the method set out in Mansur and Whalley (1984) in which the substitution elasticity $\sigma=1 /(1+\rho)$ is derived from the equation:

$$
\sigma=\frac{\eta_{i}-\gamma_{i}^{\sigma}}{1-\gamma_{i}^{\sigma}}
$$

where $\eta_{i}$ is the (uncompensated) own-price elasticity, values for which were derived as averages from Table 4 in Mansur and Whalley, and $\gamma_{i}^{\sigma}$ can be derived from ratios of consumption expenditure and our assumption that $\gamma_{A i}+\gamma_{M i}+\delta_{i}=1$.

The manufacturing sector production parameters, $\alpha_{M G}$ and $\alpha_{M L}$. were calibrated as follows. Using the firm's first-order condition for profit-maximisation, equation (7a), and the assumption that the firm can choose the government expenditure to maximize profit, we can write:

$$
\begin{aligned}
& \alpha_{M L}=\frac{W_{M} L_{M}}{Y_{M}\left(1-T_{M}\right)}, \text { and } \\
& \alpha_{M G}=\frac{G R F_{M}}{Y_{M}\left(1-T_{M}\right)}
\end{aligned}
$$

and use data for the wage bill, government infrastructure expenditure and manufacturing output net of tax to compute the parameters.

Since we assume that firms in the interior region (the agricultural sector) pay all workers the average product rather than their marginal product, we can not use the profit-maximisation condition to derive production parameters for agricultural sector. Instead, we rely on previous work which has estimated agricultural production functions of the Cobb-Douglas type from which we obtain parameter values. In particular, we use a value of 0.25 for the labour parameter $\left(\alpha_{A L}\right)$ and 0.35 for the land parameter $\left(1-\alpha_{A L}-\alpha_{G L}\right)$, based on values reported in Fan (1991) and use the constantreturns-to-scale assumption to derive a value of 0.4 for the government expenditure parameter $\left(\alpha_{G L}\right)$.

The linearisation parameters can be evaluated directly from their definitions, given values for $P, \theta, \mu, I I H_{i}, W_{j}, T_{v}, T_{j}, Y_{j}, I F_{j}, L_{j}, G C_{i}, J_{i}, G R H_{i}, G R F_{i}, G H_{i}$ and $T R_{\mathrm{i}}$. We normalise $P$ at unity and also set the immigration parameter, $\mu$, at unity; $\theta$ is set at 0.75 to reflect the current division of VAT revenue between the central and regional governments. We then use these assumed values and the data for $C_{i}, G R H_{i}, G R F_{j}$, $G C_{i}, L_{j}, W_{j}, T R_{\mathrm{i}}$ together with the model definitions to calculate the value of all other variables. The use of the model definitions ensures that the parameter values used in the simulations are consistent with the model constraints.

We therefore need data for two regions, the interior and the coast, for the variables $C_{i}, G R H_{i}, G R F_{j}, G C_{i}, L_{j}, W_{j}, T R_{\mathrm{i}}$. The data we use are based on those for the Chinese provinces which we have allocated to the two regions as follows. The coastal region consists of Beijing, Tianjin, Hebei, Guangdong, Hainan, Shandong, Fujian, Zhejiang, Jiangsu, Shanghai, Liaoning and Guangxi with the remaining provinces being allocated to the interior region. The interior therefore consist of: Shanxi, Inner 
Mongolia, Jilin, Heilongjiang, Anhui, Jiangxi, Henan, Hubei, Hunan, Sichuan, Chongqing, Guizhou, Yunnan, Shaanxi, Gansu, Qinghai, Ningxia, Tibet, Xinjiang. A map of the two regions is provided in Figure 1.

For each region we use data averaged over the seven-year period 2000-2006 to avoid cyclical influences on the share parameters. All the data come from China Statistics Year Book (SSB, various issues) except for data on area used to compute population density for the migration equilibrium condition, equation (4'), which come from China Civil Affairs Statistical Yearbook 2005 (SSB, 2005). 
ECONOMICS DISCUSSION PAPERS

2009

\begin{tabular}{|c|c|c|}
\hline $\begin{array}{l}\text { DP } \\
\text { NUMBER }\end{array}$ & AUTHORS & TITLE \\
\hline 09.01 & Le, A.T. & $\begin{array}{l}\text { ENTRY INTO UNIVERSITY: ARE THE CHILDREN OF } \\
\text { IMMIGRANTS DISADVANTAGED? }\end{array}$ \\
\hline 09.02 & $\mathrm{Wu}, \mathrm{Y}$. & CHINA'S CAPITAL STOCK SERIES BY REGION AND SECTOR \\
\hline 09.03 & Chen, M.H. & $\begin{array}{l}\text { UNDERSTANDING WORLD COMMODITY PRICES RETURNS, } \\
\text { VOLATILITY AND DIVERSIFACATION }\end{array}$ \\
\hline 09.04 & Velagic, R. & UWA DISCUSSION PAPERS IN ECONOMICS: THE FIRST 650 \\
\hline 09.05 & McLure, M. & $\begin{array}{l}\text { ROYALTIES FOR REGIONS: ACCOUNTABILITY AND } \\
\text { SUSTAINABILITY }\end{array}$ \\
\hline 09.06 & Chen, A. and Groenewold, N. & $\begin{array}{l}\text { REDUCING REGIONAL DISPARITIES IN CHINA: AN } \\
\text { EVALUATION OF ALTERNATIVE POLICIES }\end{array}$ \\
\hline 09.07 & Groenewold, N. and Hagger, A. & $\begin{array}{l}\text { THE REGIONAL ECONOMIC EFFECTS OF IMMIGRATION: } \\
\text { SIMULATION RESULTS FROM A SMALL CGE MODEL. }\end{array}$ \\
\hline 09.08 & Clements, K. and Chen, D. & AFFLUENCE AND FOOD: SIMPLE WAY TO INFER INCOMES \\
\hline 09.09 & Clements, K. and Maesepp, M. & A SELF-REFLECTIVE INVERSE DEMAND SYSTEM \\
\hline 09.10 & Jones, C. & $\begin{array}{l}\text { MEASURING WESTERN AUSTRALIAN HOUSE PRICES: } \\
\text { METHODS AND IMPLICATIONS }\end{array}$ \\
\hline 09.11 & Siddique, M.A.B. & $\begin{array}{l}\text { WESTERN AUSTRALIA-JAPAN MINING CO-OPERATION: AN } \\
\text { HISTORICAL OVERVIEW }\end{array}$ \\
\hline 09.12 & Weber, E.J. & $\begin{array}{l}\text { PRE-INDUSTRIAL BIMETALLISM: THE INDEX COIN } \\
\text { HYPTHESIS }\end{array}$ \\
\hline 09.13 & McLure, M. & $\begin{array}{l}\text { PARETO AND PIGOU ON OPHELIMITY, UTILITY AND } \\
\text { WELFARE: IMPLICATIONS FOR PUBLIC FINANCE }\end{array}$ \\
\hline 09.14 & Weber, E.J. & $\begin{array}{l}\text { WILFRED EDWARD GRAHAM SALTER: THE MERITS OF A } \\
\text { CLASSICAL ECONOMIC EDUCATION }\end{array}$ \\
\hline 09.15 & Tyers, R. and Huang, L. & $\begin{array}{l}\text { COMBATING CHINA'S EXPORT CONTRACTION: FISCAL } \\
\text { EXPANSION OR ACCELERATED INDUSTRIAL REFORM }\end{array}$ \\
\hline 09.16 & $\begin{array}{l}\text { Zweifel, P., Plaff, D. and } \\
\text { Kühn, J. }\end{array}$ & $\begin{array}{l}\text { IS REGULATING THE SOLVENCY OF BANKS COUNTER- } \\
\text { PRODUCTIVE? }\end{array}$ \\
\hline 09.17 & Clements, $\mathrm{K}$. & THE PHD CONFERENCE REACHES ADULTHOOD \\
\hline 09.18 & McLure, M. & $\begin{array}{l}\text { THIRTY YEARS OF ECONOMICS: UWA AND THE WA } \\
\text { BRANCH OF THE ECONOMIC SOCIETY FROM } 1963 \text { TO } 1992\end{array}$ \\
\hline 09.19 & Harris, R.G. and Robertson, P. & $\begin{array}{l}\text { TRADE, WAGES AND SKILL ACCUMULATION IN THE } \\
\text { EMERGING GIANTS }\end{array}$ \\
\hline 09.20 & $\begin{array}{l}\text { Peng, J., Cui, J., Qin, F. and } \\
\text { Groenewold, N. }\end{array}$ & STOCK PRICES AND THE MACRO ECONOMY IN CHINA \\
\hline 09.21 & Chen, A. and Groenewold, N. & $\begin{array}{l}\text { REGIONAL EQUALITY AND NATIONAL DEVELOPMENT IN } \\
\text { CHINA: IS THERE A TRADE-OFF? }\end{array}$ \\
\hline
\end{tabular}


ECONOMICS DISCUSSION PAPERS

2010

\begin{tabular}{|c|c|c|}
\hline $\begin{array}{l}\text { DP } \\
\text { NUMBER }\end{array}$ & AUTHORS & TITLE \\
\hline 10.01 & Hendry, D.F. & $\begin{array}{l}\text { RESEARCH AND THE ACADEMIC: A TALE OF } \\
\text { TWO CULTURES }\end{array}$ \\
\hline 10.02 & McLure, M., Turkington, D. and Weber, E.J. & A CONVERSATION WITH ARNOLD ZELLNER \\
\hline 10.03 & $\begin{array}{l}\text { Butler, D.J., Burbank, V.K. and } \\
\text { Chisholm, J.S. }\end{array}$ & $\begin{array}{l}\text { THE FRAMES BEHIND THE GAMES: PLAYER'S } \\
\text { PERCEPTIONS OF PRISONER'S DILEMMA, } \\
\text { CHICKEN, DICTATOR, AND ULTIMATUM GAMES }\end{array}$ \\
\hline 10.04 & Harris, R.G., Robertson, P.E. and Xu, J.Y. & $\begin{array}{l}\text { THE INTERNATIONAL EFFECTS OF CHINA'S } \\
\text { GROWTH, TRADE AND EDUCATION BOOMS }\end{array}$ \\
\hline 10.05 & Clements, K.W., Mongey, S. and Si, J. & $\begin{array}{l}\text { THE DYNAMICS OF NEW RESOURCE PROJECTS } \\
\text { A PROGRESS REPORT }\end{array}$ \\
\hline 10.06 & Costello, G., Fraser, P. and Groenewold, N. & $\begin{array}{l}\text { HOUSE PRICES, NON-FUNDAMENTAL } \\
\text { COMPONENTS AND INTERSTATE SPILLOVERS: } \\
\text { THE AUSTRALIAN EXPERIENCE }\end{array}$ \\
\hline 10.07 & Clements, $\mathrm{K}$. & $\begin{array}{l}\text { REPORT OF THE } 2009 \text { PHD CONFERENCE IN } \\
\text { ECONOMICS AND BUSINESS }\end{array}$ \\
\hline 10.08 & Robertson, P.E. & $\begin{array}{l}\text { INVESTMENT LED GROWTH IN INDIA: HINDU } \\
\text { FACT OR MYTHOLOGY? }\end{array}$ \\
\hline 10.09 & Fu, D., Wu, Y. and Tang, Y. & $\begin{array}{l}\text { THE EFFECTS OF OWNERSHIP STRUCTURE AND } \\
\text { INDUSTRY CHARACTERISTICS ON EXPORT } \\
\text { PERFORMANCE }\end{array}$ \\
\hline 10.10 & Wu, Y. & $\begin{array}{l}\text { INNOVATION AND ECONOMIC GROWTH IN } \\
\text { CHINA }\end{array}$ \\
\hline 10.11 & Stephens, B.J. & $\begin{array}{l}\text { THE DETERMINANTS OF LABOUR FORCE } \\
\text { STATUS AMONG INDIGENOUS AUSTRALIANS }\end{array}$ \\
\hline 10.12 & Davies, M. & $\begin{array}{l}\text { FINANCING THE BURRA BURRA MINES, SOUTH } \\
\text { AUSTRALIA: LIQUIDITY PROBLEMS AND } \\
\text { RESOLUTIONS }\end{array}$ \\
\hline 10.13 & Tyers, R. and Zhang, Y. & APPRECIATING THE RENMINBI \\
\hline 10.14 & Clements, K.W., Lan, Y. and Seah, S.P. & $\begin{array}{l}\text { THE BIG MAC INDEX TWO DECADES ON } \\
\text { AN EVALUATION OF BURGERNOMICS }\end{array}$ \\
\hline 10.15 & Robertson, P.E. and Xu, J.Y. & $\begin{array}{l}\text { IN CHINA'S WAKE: } \\
\text { HAS ASIA GAINED FROM CHINA'S GROWTH? }\end{array}$ \\
\hline 10.16 & Clements, K.W. and Izan, H.Y. & $\begin{array}{l}\text { THE PAY PARITY MATRIX: A TOOL FOR } \\
\text { ANALYSING THE STRUCTURE OF PAY }\end{array}$ \\
\hline 10.17 & Gao, G. & WORLD FOOD DEMAND \\
\hline 10.18 & Wu, Y. & $\begin{array}{l}\text { INDIGENOUS INNOVATION IN CHINA: } \\
\text { IMPLICATIONS FOR SUSTAINABLE GROWTH }\end{array}$ \\
\hline 10.19 & Robertson, P.E. & DECIPHERING THE HINDU GROWTH EPIC \\
\hline 10.20 & Stevens, G. & $\begin{array}{l}\text { RESERVE BANK OF AUSTRALIA-THE ROLE OF } \\
\text { FINANCE }\end{array}$ \\
\hline 10.21 & Widmer, P.K., Zweifel, P. and Farsi, M. & $\begin{array}{l}\text { ACCOUNTING FOR HETEROGENEITY IN THE } \\
\text { MEASUREMENT OF HOSPITAL PERFORMANCE }\end{array}$ \\
\hline 10.22 & McLure, M. & $\begin{array}{l}\text { ASSESSMENTS OF A. C. PIGOU'S FELLOWSHIP } \\
\text { THESES }\end{array}$ \\
\hline
\end{tabular}




\begin{tabular}{|l|l|l|}
\hline 10.23 & Poon, A.R. & $\begin{array}{l}\text { THE ECONOMICS OF NONLINEAR PRICING: } \\
\text { EVIDENCE FROM AIRFARES AND GROCERY } \\
\text { PRICES }\end{array}$ \\
\hline 10.24 & Halperin, D. & $\begin{array}{l}\text { FORECASTING METALS RETURNS: A BAYESIAN } \\
\text { DECISION THEORETIC APPROACH }\end{array}$ \\
\hline 10.25 & Clements, K.W. and Si. J. & $\begin{array}{l}\text { THE INVESTMENT PROJECT PIPELINE: COST } \\
\text { ESCALATION, LEAD-TIME, SUCCESS, FAILURE } \\
\text { AND SPEED }\end{array}$ \\
\hline 10.26 & Chen, A., Groenewold, N. and Hagger, A.J. & $\begin{array}{l}\text { THE REGIONAL ECONOMIC EFFECTS OF A } \\
\text { REDUCTION IN CARBON EMISSIONS }\end{array}$ \\
\hline 10.27 & $\begin{array}{l}\text { Siddique, A., Selvanathan, E.A. and } \\
\text { Selvanathan, S. }\end{array}$ & $\begin{array}{l}\text { REMITTANCES AND ECONOMIC GROWTH: } \\
\text { EMPIRICAL EVIDENCE FROM BANGLADESH, } \\
\text { INDIA AND SRI LANKA }\end{array}$ \\
\hline
\end{tabular}




\section{ECONOMICS DISCUSSION PAPERS}

\section{1}

\begin{tabular}{|c|c|c|}
\hline $\begin{array}{l}\text { DP } \\
\text { NUMBER }\end{array}$ & AUTHORS & TITLE \\
\hline 11.01 & Robertson, P.E. & $\begin{array}{l}\text { DEEP IMPACT: CHINA AND THE WORLD } \\
\text { ECONOMY }\end{array}$ \\
\hline 11.02 & Kang, C. and Lee, S.H. & $\begin{array}{l}\text { BEING KNOWLEDGEABLE OR SOCIABLE? } \\
\text { DIFFERENCES IN RELATIVE IMPORTANCE OF } \\
\text { COGNITIVE AND NON-COGNITIVE SKILLS }\end{array}$ \\
\hline 11.03 & Turkington, D. & DIFFERENT CONCEPTS OF MATRIX CALCULUS \\
\hline 11.04 & Golley, J. and Tyers, R. & $\begin{array}{l}\text { CONTRASTING GIANTS: DEMOGRAPHIC CHANGE } \\
\text { AND ECONOMIC PERFORMANCE IN CHINA AND } \\
\text { INDIA }\end{array}$ \\
\hline 11.05 & Collins, J., Baer, B. and Weber, E.J. & $\begin{array}{l}\text { ECONOMIC GROWTH AND EVOLUTION: } \\
\text { PARENTAL PREFERENCE FOR QUALITY AND } \\
\text { QUANTITY OF OFFSPRING }\end{array}$ \\
\hline 11.06 & Turkington, D. & $\begin{array}{l}\text { ON THE DIFFERENTIATION OF THE LOG } \\
\text { LIKELIHOOD FUNCTION USING MATRIX } \\
\text { CALCULUS }\end{array}$ \\
\hline 11.07 & Groenewold, N. and Paterson, J.E.H. & $\begin{array}{l}\text { STOCK PRICES AND EXCHANGE RATES IN } \\
\text { AUSTRALIA: ARE COMMODITY PRICES THE } \\
\text { MISSING LINK? }\end{array}$ \\
\hline 11.08 & Chen, A. and Groenewold, N. & $\begin{array}{l}\text { REDUCING REGIONAL DISPARITIES IN CHINA: IS } \\
\text { INVESTMENT ALLOCATION POLICY EFFECTIVE? }\end{array}$ \\
\hline 11.09 & Williams, A., Birch, E. and Hancock, P. & $\begin{array}{l}\text { THE IMPACT OF ON-LINE LECTURE RECORDINGS } \\
\text { ON STUDENT PERFORMANCE }\end{array}$ \\
\hline 11.10 & Pawley, J. and Weber, E.J. & $\begin{array}{l}\text { INVESTMENT AND TECHNICAL PROGRESS IN THE } \\
\text { G7 COUNTRIES AND AUSTRALIA }\end{array}$ \\
\hline 11.11 & Tyers, R. & $\begin{array}{l}\text { AN ELEMENTAL MACROECONOMIC MODEL FOR } \\
\text { APPLIED ANALYSIS AT UNDERGRADUATE LEVEL }\end{array}$ \\
\hline 11.12 & Clements, K.W. and Gao, G. & QUALITY, QUANTITY, SPENDING AND PRICES \\
\hline 11.13 & Tyers, R. and Zhang, Y. & $\begin{array}{l}\text { JAPAN'S ECONOMIC RECOVERY: INSIGHTS FROM } \\
\text { MULTI-REGION DYNAMICS }\end{array}$ \\
\hline 11.14 & McLure, M. & A. C. PIGOU'S REJECTION OF PARETO'S LAW \\
\hline 11.15 & Kristoffersen, I. & $\begin{array}{l}\text { THE SUBJECTIVE WELLBEING SCALE: HOW } \\
\text { REASONABLE IS THE CARDINALITY } \\
\text { ASSUMPTION? }\end{array}$ \\
\hline 11.16 & Clements, K.W., Izan, H.Y. and Lan, Y. & VOLATILITY AND STOCK PRICE INDEXES \\
\hline 11.17 & Parkinson, M. & $\begin{array}{l}\text { SHANN MEMORIAL LECTURE 2011: SUSTAINABLE } \\
\text { WELLBEING - AN ECONOMIC FUTURE FOR } \\
\text { AUSTRALIA }\end{array}$ \\
\hline 11.18 & Chen, A. and Groenewold, N. & $\begin{array}{l}\text { THE NATIONAL AND REGIONAL EFFECTS OF } \\
\text { FISCAL DECENTRALISATION IN CHINA }\end{array}$ \\
\hline 11.19 & Tyers, R. and Corbett, J. & $\begin{array}{l}\text { JAPAN'S ECONOMIC SLOWDOWN AND ITS } \\
\text { GLOBAL IMPLICATIONS: A REVIEW OF THE } \\
\text { ECONOMIC MODELLING }\end{array}$ \\
\hline 11.20 & $\mathrm{Wu}, \mathrm{Y}$ & $\begin{array}{l}\text { GAS MARKET INTEGRATION: GLOBAL TRENDS } \\
\text { AND IMPLICATIONS FOR THE EAS REGION }\end{array}$ \\
\hline
\end{tabular}




\begin{tabular}{|l|l|l|}
\hline 11.21 & Fu, D., Wu, Y. and Tang, Y. & $\begin{array}{l}\text { DOES INNOVATION MATTER FOR CHINESE HIGH- } \\
\text { TECH EXPORTS? A FIRM-LEVEL ANALYSIS }\end{array}$ \\
\hline 11.22 & Fu, D. and Wu, Y. & $\begin{array}{l}\text { EXPORT WAGE PREMIUM IN CHINA'S } \\
\text { MANUFACTURING SECTOR: A FIRM LEVEL } \\
\text { ANALYSIS }\end{array}$ \\
\hline 11.23 & Li, B. and Zhang, J. & $\begin{array}{l}\text { SUBSIDIES IN AN ECONOMY WITH ENDOGENOUS } \\
\text { CYCLES OVER NEOCLASSICAL INVESTMENT AND } \\
\text { NEO-SCHUMPETERIAN INNOVATION REGIMES }\end{array}$ \\
\hline 11.24 & Krey, B., Widmer, P.K. and Zweifel, P. & $\begin{array}{l}\text { EFFICIENT PROVISION OF ELECTRICITY FOR THE } \\
\text { UNITED STATES AND SWITZERLAND }\end{array}$ \\
\hline 11.25 & Wu, Y. & $\begin{array}{l}\text { ENERGY INTENSITY AND ITS DETERMINANTS IN } \\
\text { CHINA'S REGIONAL ECONOMIES }\end{array}$ \\
\hline & & \\
\hline
\end{tabular}

